\title{
Leadership Roles for Sustainable Development: The Case of a Malaysian Green Hotel
}

\author{
Minhaz Farid Ahmed ${ }^{1, *(\mathbb{D}}$, Mazlin Bin Mokhtar ${ }^{1, *}$, Chen Kim Lim ${ }^{1}$, Anthony Wong Kim Hooi ${ }^{2}$ \\ and Khai Ern Lee ${ }^{1}$ (D) \\ 1 Institute for Environment and Development (LESTARI), University Kebangsaan Malaysia (UKM), \\ Bangi 43600, Selangor, Malaysia; kim@ukm.edu.my (C.K.L.); khaiernlee@ukm.edu.my (K.E.L.) \\ 2 The Frangipani Langkawi Resort and Spa, Jalan Teluk Baru, Pantai Tengah, Langkawi 07100, Kedah, Malaysia; \\ anthony@asianoverland.com.my \\ * Correspondence: minhaz@ukm.edu.my (M.F.A.); mazlin@ukm.edu.my (M.B.M.); \\ Tel.: +60-3-8921-3894 (M.F.A.); +60-3-8921-4144 (M.B.M.)
}

check for updates

Citation: Ahmed, M.F.; Mokhtar, M.B.; Lim, C.K.; Hooi, A.W.K.; Lee, K.E. Leadership Roles for Sustainable Development: The Case of a Malaysian Green Hotel. Sustainability 2021, 13, 10260. https://doi.org/ $10.3390 /$ su131810260

Academic Editor: Timothy Lee

Received: 6 May 2021

Accepted: 9 September 2021

Published: 14 September 2021

Publisher's Note: MDPI stays neutral with regard to jurisdictional claims in published maps and institutional affiliations.

Copyright: (c) 2021 by the authors. Licensee MDPI, Basel, Switzerland. This article is an open access article distributed under the terms and conditions of the Creative Commons Attribution (CC BY) license (https:/ / creativecommons.org/licenses/by/ $4.0 /)$.
Abstract: The leadership roles of green hotels are essential for sustainable development because of their contribution to reducing carbon emission, supplying safe food, and managing water resources. However, sustainability education has not adequately integrated entrepreneurial skills to promote green hotel practices towards sustainable development. Therefore, this study explored the leadership roles of the Frangipani Hotel in Langkawi, Malaysia, because it adopted a circular economy in line with the zero-waste concept to develop the environmental and socio-economic condition of the locality. Extensive literature reviews were conducted to explore the transformational leadership roles of the Frangipani hotel for green practices. Interviews with the managing director, general manager, and the head of 10 operating branches of Frangipani also provided information about the green hotel practices to support its leadership roles. Similarly, interviews with the public, private, business, and community stakeholders also supported the transformational leadership roles of Frangipani to integrated green hotel practices with effective multi-stakeholder collaboration for quality control and quality assurance of its green practices. The patience of Frangipani and its roles as a liaison among government, non-government, business, and private and community sectors have been very effective in promoting green practices in the hospitability industry via training and knowledgesharing. However, the monitoring and evaluation of these green practices are essential, and they can be completed via developing a special key performance index for the effective promotion of green hotels.

Keywords: hospitality industry; Malaysia; leadership roles; climate change; sustainability

\section{Introduction}

Leadership roles of individuals and institutions, especially at the local level, are imperative for sustainable development. However, research on sustainability education has neglected to incorporate entrepreneurial skills into other relevant capabilities such as foresight, complex problem solving, and interdisciplinarity approaches, although possible convergences between sustainability education and entrepreneurship education have been addressed by researchers [1]. Therefore, several ways of leadership, such as transformative, behavior, and/or collective leadership, etc., especially in the hospitality industry, have been observed [2-5], and these leadership practices required appropriate integration of all aspects related to the hospitality industry to promote green tourism. However, inadequate integration between quantitative methods and community-engaged social sciences and humanities approaches, inadequate engagement with social movements and grassroots activism, as well as some important gaps in the theorization of the commodification of nature are the challenges of sustainability leadership in the hospitality industry [6]. Moreover, barriers related to the novelty of Sustainable Product-Service Systems models require new 
attitudes to small companies, including changing mindsets from product ownership to use [7]. Green practices in hotels are the important environmental management approaches of the hospitability industry. The green practices contribute to mitigating the impact of climate change via reducing carbon emission and fostering global sustainability in line with the COP (Conference of Parties) 21 Paris Agreement of the United Nation's sustainable development goals (SDGs) in 2015. From the green marketing perspective, green hotel management not only succeeds in its corporate social responsibility in making the earth a better place to live in but also upholds its hotel image, yielding loyal customers [8]. Malaysia is one of the top tourist destinations in South East Asia [9]. Therefore, the leadership roles of the hospitality industry are very important not only in Malaysia but also in other countries to fulfill the aspiration of sustainable development goals via green tourism.

The green tourism concept came out in the early 1980s, when the hotel industry tried to initiate green practices such as placing green placards in each room that encouraged guests to reuse their towels [10]. Meanwhile, many hotels tried to greenwash the concept of the green hotel; however, most environmentally friendly hotels have information on their websites about their green initiatives that describe their conservation of natural resources, protection of plants and wildlife, and contribution to the wellbeing of local communities [10]. Besides, public awareness of green hotels can also be enhanced through an interactive website by explicitly illustrating the differences between conventional buildings as compared to green buildings and information on the impacts on the environment and green alternatives that can be found in Malaysia [11]. The concepts of sustainable tourism and ecotourism are almost alike because of many similar principles. However, the scope of sustainable hospitality is broader than ecotourism.

Sustainable tourism businesses support environmental conservation, social development, and local economies. For instance, sustainable tourism practices include conserving water and energy, supporting community conservation projects, recycling and treating wastes, hiring staff from the local community, etc., [10]. These green conservation barriers can be eliminated with Building Information Modeling (BIM). BIM is one of the effective ways to demonstrate the evolutions and the benefits of green practices dealing with materials, energy, and water efficiency during hotel constructions [12]. On the other hand, responsible travel to natural areas that conserve the environment and improve the welfare of local people is the key message of ecotourism, according to the International Ecotourism Society [13].

The greening of industry, including the hospitability industry, has been receiving importance since the 1980s because of its incremental environmental impact. For instance, the International Hotels Environmental Initiative (IHEI) has reported that the United Kingdom's hotel sector has an environmental impact similar to the oil and gas sectors [14]. Moreover, there are increasing demands for green accommodation and energy as well as sustainable disposal of waste by green tourists. Therefore, IHEI has published a manual, 'Environmental Management for Hotels: The Industry Guide to Best Practice', for hotel managers to accelerate green practices [14]. Accordingly, the American Hotel \& Lodging Association (AH \& LA) in 2014 reported that 93\% of US hotels have linen and towel reuse programs, $64 \%$ have recycling programs, and the electric car charging stations has increased from 5\% to 11\% since 2012 [15]. The United Nations Environment Programme (UNEP) reported that approximately $79 \%$ of tourists are seeking green hotels when they travel, and TripAdvisor reported that about $57 \%$ of tourists often make eco-friendly decisions when they choose accommodations or food [15]. Moreover, $23 \%$ of tourists are willing to pay up to $\$ 25$ more per night for eco-friendly accommodation in the USA. Therefore, the hospitality industry is encouraged to have more green practices and ecological campaigns $[16,17]$. 
The Davos Declaration in 2008 estimated tourism to contribute to approximately 5\% of global $\mathrm{CO}_{2}$ emissions by the study of the World Tourism Organization (UNWTO) and United Nations Environment Program (UNEP) [18]. As such, tourism is also expected to be at the forefront of the global response to climate change. Consequently, the entire tourism industry has become an important component of greenhouse gas emissions, energy conservation, and emission reduction. Therefore, the tourism industry has obtained important significance in achieving global emission reduction targets, and a large number of studies have focused on reducing tourism-related $\mathrm{CO}_{2}$ emissions. These studies have been conducted from different perspectives, all of which can be summarized to deal with the following aspect of $\mathrm{CO}_{2}$ emission reductions: technical developments [19]. Apart from climate change, uncertainties such as the COVID-19 pandemic also have a severe impact on green hotel operations, and in many aspects, have changed the way of operations [20].

Currently, all the staff at the Frangipani hotel are employed on yearly contracts or are casual. In the past, all staff members were given a permanent position. However, the Frangipani hotel has adopted strategies such as outsourcing contract employees to minimize the operational cost during the COVID-19 pandemic. This is what the business needs to survive: accept innovative ideas and implement them to be better. For example, Frangipani used to have 12 maintenance staff, and now only has 4 . Similarly, there were 14 gardeners, and now 4. However, Frangipani is now outsourcing the major works to be completed to reduce the burden on current staff because the management authority needs to be practical.

Frangipani has also closed FnB (i.e., Food and Beverage) services during the COVID19 pandemic because there are very few tourists. The majority of the few check-in tourists do not eat breakfast at the restaurant of Frangipani because they want to eat cheaply outside, although Frangipani has reduced the food price by about $60 \%$ in the past. Hence, Frangipani is targeting the local market by reducing the FnB pricing up to $80 \%$ compared to the past. However, the reduction of the FnB price differs by the business owners to be suitable for their business. Frangipani has also put a limit on room services that is appropriate with the current number of staff. For instance, Frangipani now only sells a maximum of 30 rooms and an inventory of 60 to be manageable by the current number of staff. Frangipani has remained on the star rating list for the last 5 years, and not all hotels can comply with the star rating guidelines in this pandemic situation. Hence, the MOTAC (Ministry of Tourism, Arts and Culture) has suspended this star rating exercise of the hospitality industry during this pandemic.

Frangipani Langkawi Resort and Spa adopted the Environmental Action Plan for Hotel by the UNEP in 1995, the Green Building Index (GBI), ASEAN green hotel standards, and therefore, enhanced brand value through reducing consumption and cost and increasing customer loyalty and dedicated staff for long-term benefits. Frangipani Langkawi Resort and Spa has been located in the Langkawi UNESCO Global Geopark since 2007, which is in the far north-western corner of peninsular Malaysia. This island along the Straits of Malacca is a famous historical trade route in South East Asia. This legendary Langkawi Archipelago heritage, combined with the traditional fishing and farming village, maximize the experience with natural and cultural heritage. Therefore, ecotourism has been promoted on the island for sustainable development [21,22]. Thus, the Frangipani Langkawi Resort and Spa has been chosen as a case of a green hotel for this study (Figure 1). 


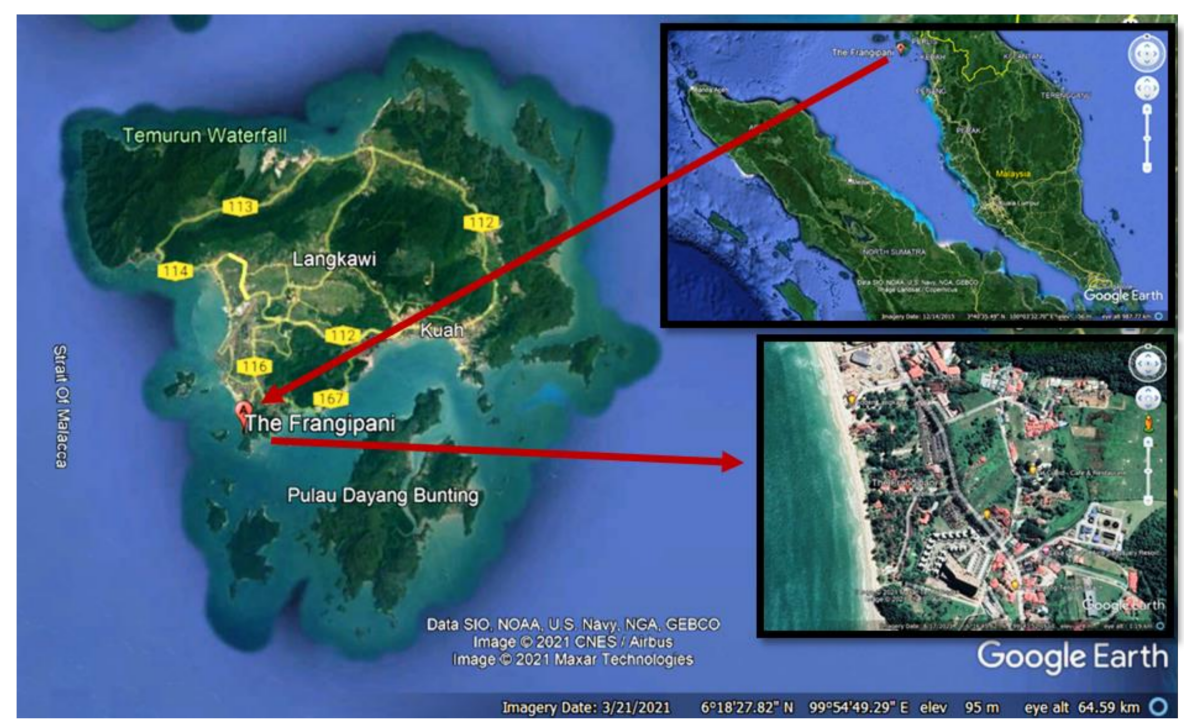

Figure 1. Frangipani Langkawi Resort and Spa in Langkawi, Malaysia [23].

However, due to the inadequate proactive leadership roles of these hotels, environmental reporting has not been incorporated with financial reporting until the environmental concern became a strategic issue [14]. Less participation in indoor air quality, sustainable management of the site, renewable energy, and rainwater harvesting system have been observed in green hotel approaches in Malaysia [24]. Although the business sector, including the hotels in Malaysia, is subject to licensing from the local authorities and bound to comply with the policies of the country, the hotel sector is not taking a proactive approach to environmental concerns except a few. While there is much emphasis on authentic green practices, there is rising concern about the common practice of greenwashing [25]. Green or eco-friendly hotels and services have gained tremendous relevance to reduce the environmental impact of the tourist and hospitality industry. Therefore, the managerial and marketing benefits are the most important driving forces to link green initiatives and action plans [26]. The Frangipani Langkawi Resort and Spa in Langkawi, Malaysia, has adopted the circular economy to strengthen the green practices in its hotel. A circular economy fosters the transition towards a more resource-efficient economy, which can boost economic performance while reducing resource use and negative environmental externalities $[27,28]$. The modified circular economy at the Frangipani Hotel has included the local community and tourists through organic farming and composting, waste management, water and energy savings, water purification through constructed wetland, etc., [29].

Mittal and Dhar [2], in a leadership study, reported that green transformational leadership is positively related to the promotion of green creativity in the organization when considering resource commitment. In addition, Abdou et al. [3] also reported that $63 \%$ of the total Certified Green Star hotels that have environmental representatives in the hotels in Egypt contributed positively to achieving environment-related goals, namely, SDG 6, SDG 12, SDG 7, and SDG 13. In other words, sustainability matters to the hotel's key players as the social responsibility investments clearly resulted in the hotel's financial values and performance in the long run whilst bringing benefits to society [4]. Besides, a development of collective leadership to form a network among the stakeholders is needed to be established to make a difference and change in tourism workplaces and destinations [5]. Therefore, green hotels have to increase their resource commitment for the promotion of green creativity amongst their employees. Frangipani Langkawi Resort and Spa is keen to continue the green hotel practices of environmental, economic, and sociocultural sustainability. However, the integration of these green practices, along with inadequate collaboration among stakeholders, remains challenging to fulfill the aspiration of sustainable development. Thus, this study explored the transformational and behavioral 
leadership roles of Frangipani Hotel via bringing science and technology to the local multistakeholders platform for green hotel practices to enhance sustainable development.

\section{Literature Review}

The theory of transformational leadership was introduced by James MacGregor Burns [30] in his descriptive research on political leaders, although it has also been used by researchers in organizational psychology [31-34]. Transformational leadership focuses on how leaders can create valuable and positive change in their followers with the end goal of developing followers into leaders. On the other hand, John B. Watson [35] introduced the Behavioral Theory of leadership in his classic paper, 'Psychology as the Behaviorist Views It' [36]. The Behavioral Theory of leadership focus on the specific behaviors and actions of leaders rather than their traits or characteristics. The theory suggests that effective leadership is the result of many learned skills. Individuals need three primary skills to lead their followers-technical, human, and conceptual skills. Technical skills refer to a leader's knowledge of the process or technical skills for environmental conservation, human skills refer to one's skill to interact with others for social inclusiveness, and conceptual skills enable the leader to come up with ideas for running the organization and promote green growth [35,37]. Meanwhile, many researchers have used the behavioral theory of leadership for sustainability (Table 1).

Table 1. Literature review on leadership for sustainability (2015-2021).

\begin{tabular}{|c|c|c|c|c|c|}
\hline Author and Year & Country & Objectives & Variables & Methods & Results \\
\hline $\begin{array}{l}\text { Kim and Hall, } \\
2021[38]\end{array}$ & Korea & $\begin{array}{l}\text { To utilize theories of } \\
\text { value-attitude-behavior } \\
\text { (VAB) model and } \\
\text { personality to } \\
\text { investigate Korean } \\
\text { consumer } \\
\text { crowdfunding behavior } \\
\text { for sustainability } \\
\text { initiatives. }\end{array}$ & $\begin{array}{l}\text { Value, attitude, personal } \\
\text { norm, and social norm } \\
\text { on sustainability, and } \\
\text { participation in } \\
\text { sustainability } \\
\text { crowdfunding. }\end{array}$ & $\begin{array}{l}\text { Value-attitude- } \\
\text { behavior (VAB) } \\
\text { model. }\end{array}$ & $\begin{array}{l}\text { Value has substantial impacts } \\
\text { on attitude, personal norm, } \\
\text { and social norm. Attitude, } \\
\text { personal norm, and social } \\
\text { norm on consumer } \\
\text { crowdfunding sources are } \\
\text { found to have positive impacts } \\
\text { on participation. }\end{array}$ \\
\hline $\begin{array}{l}\text { Apostolopoulou } \\
\text { et al., 2021 [6] }\end{array}$ & Global & $\begin{array}{l}\text { To explore the principal } \\
\text { ways in which } \\
\text { conservation is } \\
\text { neoliberalized in } \\
\text { practice. }\end{array}$ & $\begin{array}{l}\text { Peer-reviewed } \\
\text { scholarship, key } \\
\text { processes of } \\
\text { neoliberalization. }\end{array}$ & $\begin{array}{c}\text { Descriptive statistics } \\
\text { and thematic content } \\
\text { analysis. }\end{array}$ & $\begin{array}{l}\text { A shift towards a decolonial, } \\
\text { interdisciplinary, intersectional, } \\
\text { community-engaged approach } \\
\text { and an in-depth encounter } \\
\text { with everyday practices of } \\
\text { resistance is important for } \\
\text { conservation in neoliberalized } \\
\text { principal. }\end{array}$ \\
\hline $\begin{array}{l}\text { Milner-Gulland } \\
\text { et al., 2021 [39] }\end{array}$ & England & $\begin{array}{l}\text { To restore nature while } \\
\text { meeting human needs } \\
\text { requires a bold vision. }\end{array}$ & $\begin{array}{l}\text { National governments, } \\
\text { sub-national levels, } \\
\text { companies, and } \\
\text { individuals. }\end{array}$ & $\begin{array}{c}\text { Mitigation and } \\
\text { Conservation Hierarchy. }\end{array}$ & $\begin{array}{l}\text { The Mitigation and } \\
\text { Conservation Hierarchy } \\
\text { supports the choice of actions } \\
\text { to conserve and restore nature, } \\
\text { and evaluation of the } \\
\text { effectiveness of those actions, } \\
\text { across sectors and scales. }\end{array}$ \\
\hline $\begin{array}{l}\text { Del Campo et al., } \\
2020[40]\end{array}$ & $\begin{array}{c}\text { Ireland, Italy, and } \\
\text { Kenya }\end{array}$ & $\begin{array}{l}\text { To explore the extent to } \\
\text { which the community } \\
\text { has reflected upon } \\
\text { SEA's role in delivering } \\
\text { the SDGs. }\end{array}$ & $\begin{array}{l}\text { Strategic Environmental } \\
\text { Assessment. }\end{array}$ & $\begin{array}{c}\text { Systematic literature } \\
\text { review. }\end{array}$ & $\begin{array}{l}\text { Operationalization of SDGs } \\
\text { provides training for a more } \\
\text { proactive integration of } \\
\text { objectives and targets of the } \\
\text { Strategic Environmental } \\
\text { Assessment (SEA). }\end{array}$ \\
\hline $\begin{array}{l}\text { Hermann and } \\
\text { Bossle, } 2020[1]\end{array}$ & Global & $\begin{array}{c}\text { To explore } \\
\text { entrepreneurial } \\
\text { competences in higher } \\
\text { education in order to be } \\
\text { taught in sustainability } \\
\text { education programs. }\end{array}$ & $\begin{array}{l}\text { Teaching-learning } \\
\text { approaches and } \\
\text { external collaboration. }\end{array}$ & Bibliometric method. & $\begin{array}{l}\text { Education for sustainable } \\
\text { development across } \\
\text { educational programs brings } \\
\text { solutions for complex } \\
\text { community problems by } \\
\text { engaging businesses and } \\
\text { consumers related to } \\
\text { sustainability issues. }\end{array}$ \\
\hline $\begin{array}{l}\text { Kantabutra and } \\
\text { Ketprapakorn, } \\
2020[41]\end{array}$ & Global & $\begin{array}{l}\text { To explore sustainability } \\
\text { organizational culture } \\
\text { comprising } \\
\text { sustainability vision } \\
\text { and values leads to } \\
\text { emotional commitment } \\
\text { among organizational } \\
\text { members. }\end{array}$ & $\begin{array}{l}\text { Perseverance, resilience } \\
\text { development, } \\
\text { moderation, geosocial } \\
\text { development, } \\
\text { and sharing. }\end{array}$ & Qualitative study. & $\begin{array}{l}\text { Corporate sustainability } \\
\text { asserts that the sustainability } \\
\text { organizational culture } \\
\text { comprising sustainability } \\
\text { vision and values leads to } \\
\text { emotional commitment among } \\
\text { organizational members to } \\
\text { attain the vision. }\end{array}$ \\
\hline
\end{tabular}


Table 1. Cont.

\begin{tabular}{|c|c|c|c|c|c|}
\hline Author and Year & Country & Objectives & Variables & Methods & Results \\
\hline $\begin{array}{l}\text { Potdar et al., } \\
2020[42]\end{array}$ & New Zealand & $\begin{array}{c}\text { To examine how } \\
\text { employers' corporate } \\
\text { social responsibility } \\
\text { involvement influences } \\
\text { employee proclivity } \\
\text { towards guardianship } \\
\text { behavior in shoplifting } \\
\text { prevention. }\end{array}$ & $\begin{array}{l}\text { Employers' corporate } \\
\text { social responsibility. }\end{array}$ & $\begin{array}{l}\text { Semi-structured } \\
\text { interview. }\end{array}$ & $\begin{array}{l}\text { A reduction in retail crime } \\
\text { contributes towards positive } \\
\text { relationships among key } \\
\text { stakeholders such as } \\
\text { supermarkets, their employees, } \\
\text { and society at large based on } \\
\text { the social, environmental, and } \\
\text { employee welfare practices of } \\
\text { supermarkets. }\end{array}$ \\
\hline $\begin{array}{l}\text { Prashar and Vijaya, } \\
2020[43]\end{array}$ & Global & $\begin{array}{c}\text { To present a state of the } \\
\text { art literature review on } \\
\text { sustainable } \\
\text { development in SMEs. }\end{array}$ & $\begin{array}{c}\text { Small- and } \\
\text { medium-sized } \\
\text { enterprises (SMEs). }\end{array}$ & $\begin{array}{c}\text { Systematic literature } \\
\text { review. }\end{array}$ & $\begin{array}{l}\text { The applications of key } \\
\text { management tools (such as } \\
\text { tools for CSR management, } \\
\text { environment management, } \\
\text { LCA (life-cycle assessments), } \\
\text { and sustainability evaluation } \\
\text { indicators) are helpful for } \\
\text { managers to integrate } \\
\text { sustainability into SMEs' } \\
\text { business strategy. }\end{array}$ \\
\hline $\begin{array}{c}\text { Stojanovic and Gee, } \\
2020[44]\end{array}$ & Global & $\begin{array}{l}\text { To understand whether } \\
\text { marine planning really } \\
\text { is leading towards } \\
\text { sustainability. }\end{array}$ & $\begin{array}{l}\text { Marine spatial } \\
\text { planning. }\end{array}$ & $\begin{array}{c}\text { Reviews analytical } \\
\text { debates and empirical } \\
\text { evidence. }\end{array}$ & $\begin{array}{l}\text { This paper outlines five key } \\
\text { major theoretical approaches } \\
\text { for governance and reviews } \\
\text { analytical debates and } \\
\text { empirical findings of marine } \\
\text { planning using those } \\
\text { approaches. }\end{array}$ \\
\hline $\begin{array}{l}\text { Su and Chen, } \\
2020 \text { [4] }\end{array}$ & USA & $\begin{array}{l}\text { To analyze whether } \\
\text { Dow Jones } \\
\text { Sustainability North } \\
\text { America Index (DJSI) } \\
\text { generates short- and } \\
\text { long-run impacts on } \\
\text { hospitality firms' } \\
\text { financial values. }\end{array}$ & $\begin{array}{c}\text { Dow Jones } \\
\text { Sustainability North } \\
\text { America Index (DJSI). }\end{array}$ & Event study model. & $\begin{array}{l}\text { Institutional ownership paves } \\
\text { the way to develop new } \\
\text { socially responsible investment } \\
\text { strategies and ESG } \\
\text { (environmental, social, and } \\
\text { corporate } \\
\text { governance)-oriented practices } \\
\text { that help consolidate } \\
\text { tourism-related firms' financial } \\
\text { performance and positively } \\
\text { benefit society. }\end{array}$ \\
\hline $\begin{array}{l}\text { Zach et al., } \\
2020[45]\end{array}$ & Global & $\begin{array}{l}\text { To analyze the market } \\
\text { value impact of actions } \\
\text { taken in response to } \\
\text { disruptive innovation. }\end{array}$ & $\begin{array}{l}\text { Incumbent tourism } \\
\text { firms. }\end{array}$ & Event study. & $\begin{array}{l}\text { Adoption speeds, that is, first } \\
\text { vs. late adoption, make a } \\
\text { difference as the former is } \\
\text { awarded a significant increase } \\
\text { in market value. }\end{array}$ \\
\hline $\begin{array}{l}\text { Zhang et al., } \\
2020 \text { [46] }\end{array}$ & China & $\begin{array}{l}\text { To explore the positive } \\
\text { effect of } \\
\text { standards-setting } \\
\text { involvements on } \\
\text { corporate innovation in } \\
\text { China. }\end{array}$ & $\begin{array}{c}\text { Effect of } \\
\text { standards-setting } \\
\text { involvements on } \\
\text { corporate innovation. }\end{array}$ & Empirical evidence. & $\begin{array}{c}\text { Standards-setting } \\
\text { involvements foster innovation } \\
\text { mainly through improving } \\
\text { firms' R\&D efficiency, reducing } \\
\text { financial constraints, and } \\
\text { inducing collaborative } \\
\text { innovation. }\end{array}$ \\
\hline $\begin{array}{l}\text { Pope et al., } \\
2019 \text { [47] }\end{array}$ & South Africa & $\begin{array}{l}\text { To find out parallels in } \\
\text { the discourses of EIA } \\
\text { and responsible } \\
\text { tourism. }\end{array}$ & $\begin{array}{l}\text { Sustainable and } \\
\text { responsible tourism. }\end{array}$ & $\begin{array}{l}\text { Focused literature } \\
\text { review. }\end{array}$ & $\begin{array}{l}\text { A framework comprising five } \\
\text { characteristics that EIA should } \\
\text { embody to maximize its } \\
\text { contribution to responsible } \\
\text { tourism. }\end{array}$ \\
\hline $\begin{array}{l}\text { Gardas et al., } \\
2019 \text { [48] }\end{array}$ & India & $\begin{array}{l}\text { To analyze the barriers } \\
\text { to sustainable human } \\
\text { resource management } \\
\text { with a focus on talent } \\
\text { management in the } \\
\text { Indian oil and } \\
\text { gas sector. }\end{array}$ & $\begin{array}{l}\text { High attrition rate, lack } \\
\text { of talent supply from } \\
\text { the academic institutes, } \\
\text { insufficient knowledge } \\
\text { transfer. }\end{array}$ & $\begin{array}{l}\text { Interpretive structural } \\
\text { modeling technique. }\end{array}$ & $\begin{array}{l}\text { 'Uncertain career growth', } \\
\text { 'industry dynamism', and 'lack } \\
\text { of training programs' are the } \\
\text { significant barriers to corporate } \\
\text { sustainability. }\end{array}$ \\
\hline $\begin{array}{l}\text { Molinillo et al., } \\
\text { 2019 [49] }\end{array}$ & Spain & $\begin{array}{l}\text { To explore a unique } \\
\text { conceptual model and } \\
\text { methodology } \\
\text { incorporating } \\
\text { popularity, } \\
\text { commitment, and } \\
\text { virality to measure the } \\
\text { social media } \\
\text { engagement with } \\
\text { residents and visitors of } \\
\text { smart cities. }\end{array}$ & $\begin{array}{l}\text { Popularity, } \\
\text { commitment, } \\
\text { and virality. }\end{array}$ & Digital content analysis. & $\begin{array}{l}\text { Spanish smart cities have } \\
\text { considerable scope to improve } \\
\text { their use of social media to } \\
\text { enhance their communications } \\
\text { and branding while } \\
\text { prioritizing emotional } \\
\text { messages and business events. }\end{array}$ \\
\hline
\end{tabular}


Table 1. Cont.

\begin{tabular}{|c|c|c|c|c|c|}
\hline Author and Year & Country & Objectives & Variables & Methods & Results \\
\hline $\begin{array}{l}\text { de Jesus Pacheco } \\
\text { et al., } 2019 \text { [7] }\end{array}$ & Global & $\begin{array}{l}\text { To identify the main } \\
\text { barriers involving the } \\
\text { transition towards } \\
\text { sustainable } \\
\text { product-service } \\
\text { systems in } \\
\text { manufacturing SMEs as } \\
\text { well as the strategies to } \\
\text { overcome them. }\end{array}$ & $\begin{array}{l}\text { Financial resources, } \\
\text { competences, mentality, } \\
\text { and resistance to } \\
\text { change. }\end{array}$ & $\begin{array}{c}\text { Systematic literature } \\
\text { review. }\end{array}$ & $\begin{array}{c}\text { Internal barriers associated } \\
\text { with intrinsic characteristics of } \\
\text { SMEs become still more } \\
\text { sensitive during the transition } \\
\text { (e.g., limited financial } \\
\text { resources, the lack of } \\
\text { competences, follower } \\
\text { mentality, and resistance } \\
\text { to change). }\end{array}$ \\
\hline $\begin{array}{l}\text { Pisters et al., } \\
2019 \text { [50] }\end{array}$ & Global & $\begin{array}{l}\text { To research the extent to } \\
\text { which people involved } \\
\text { in place-based } \\
\text { sustainability initiatives } \\
\text { develop an ecological } \\
\text { consciousness. }\end{array}$ & $\begin{array}{l}\text { (Re-)connection, } \\
\text { (self-)compassion, and } \\
\text { creativity. }\end{array}$ & $\begin{array}{l}\text { Critical literature } \\
\text { review. }\end{array}$ & $\begin{array}{c}\text { Transformative learning (TL) } \\
\text { that fosters a shift in } \\
\text { consciousness towards a more } \\
\text { ecological approach is an } \\
\text { inherently place-based } \\
\text { phenomenon. }\end{array}$ \\
\hline $\begin{array}{l}\text { Barani et al., } \\
2018 \text { [51] }\end{array}$ & Global & $\begin{array}{c}\text { To explore world's } \\
\text { ecovillages for } \\
\text { achieving a framework } \\
\text { that can provide a } \\
\text { common mental model } \\
\text { for developing available } \\
\text { ecovillages. }\end{array}$ & $\begin{array}{l}\text { Ecovillage, sustainable } \\
\text { society, intentional } \\
\text { communities, case } \\
\text { study, and } \\
\text { eco-community. }\end{array}$ & $\begin{array}{c}\text { Qualitative } \\
\text { meta-analysis, } \\
\text { systematic literature } \\
\text { review. }\end{array}$ & $\begin{array}{l}\text { Analyzing the integrity of the } \\
\text { ecovillage is an } \\
\text { interdisciplinary subject, which } \\
\text { requires a variety of expertise } \\
\text { to address the aspects such as } \\
\text { energy, building design, water, } \\
\text { agriculture, and so on. } \\
\text { Therefore, evaluating all } \\
\text { dimensions and characteristics } \\
\text { of ecovillages is beyond the } \\
\text { experience of a researcher. }\end{array}$ \\
\hline $\begin{array}{c}\text { Pope et al., } 2018 \\
\text { [52] }\end{array}$ & Australia & $\begin{array}{l}\text { To test the broader } \\
\text { utility of the } \\
\text { sustainability } \\
\text { assessment } \\
\text { effectiveness framework } \\
\text { by applying it to a } \\
\text { controversial strategic } \\
\text { assessment case study. }\end{array}$ & $\begin{array}{c}\text { Procedural, substantive, } \\
\text { trans-active, normative, } \\
\text { pluralism, and } \\
\text { knowledge and } \\
\text { learning. }\end{array}$ & Document review. & $\begin{array}{l}\text { The concept of substantive } \\
\text { effectiveness should be } \\
\text { expanded to incorporate the } \\
\text { unintended consequences of } \\
\text { impact assessment. }\end{array}$ \\
\hline Tasci, 2018 [53] & USA & $\begin{array}{c}\text { To analyze } \\
\text { consumer/customer- } \\
\text { based brand equity } \\
\text { models for different } \\
\text { segments based on } \\
\text { nationality, gender, and } \\
\text { past visitation. }\end{array}$ & $\begin{array}{l}\text { Consumer/customer- } \\
\text { based brand equity } \\
\text { models. }\end{array}$ & Path analysis. & $\begin{array}{c}\text { Familiarity and image were the } \\
\text { two most prominent } \\
\text { components explaining loyalty } \\
\text { in both } \\
\text { consumer-/customer-based } \\
\text { brand equity models, although } \\
\text { both consumer value and } \\
\text { brand value also had some } \\
\text { mediating effects on loyalty. }\end{array}$ \\
\hline Balsas, 2017 [54] & USA and Portugal & $\begin{array}{l}\text { To examine regional } \\
\text { planning for territorial } \\
\text { coherence. }\end{array}$ & $\begin{array}{l}\text { Urban development } \\
\text { patterns, regulatory and } \\
\text { administrative planning } \\
\text { traditions, } \\
\text { socio-economic and } \\
\text { cultural systems. }\end{array}$ & Comparative analysis. & $\begin{array}{l}\text { Anticipatory regional planning } \\
\text { has the capacity to adapt to } \\
\text { changing conditions in order to } \\
\text { maintain and develop more } \\
\text { sustainable and resilient } \\
\text { territories. }\end{array}$ \\
\hline Guerin, 2017 [55] & Australia & $\begin{array}{l}\text { To confirm and clarify } \\
\text { the nature of } \\
\text { environmental and } \\
\text { community risks to be } \\
\text { expected on Australian } \\
\text { solar photovoltaic } \\
\text { construction sites. }\end{array}$ & $\begin{array}{c}\text { Engineering } \\
\text { procurement } \\
\text { construction (EPC), } \\
\text { end-of-life packaging } \\
\text { materials (EOLPMs). }\end{array}$ & Desktop study. & $\begin{array}{l}\text { Majority of the risks actually } \\
\text { experienced in the field during } \\
\text { the construction phase. }\end{array}$ \\
\hline $\begin{array}{l}\text { Király et al., } \\
2017 \text { [56] }\end{array}$ & Global & $\begin{array}{l}\text { To understand how } \\
\text { leaders acquire and } \\
\text { process information and } \\
\text { how their systems } \\
\text { thinking perspectives } \\
\text { guide their cognitive } \\
\text { procedures when } \\
\text { turning pieces of } \\
\text { information into policy } \\
\text { interventions. }\end{array}$ & $\begin{array}{c}\text { Individual filter } \\
\text { (political leaders'), } \\
\text { political filter, } \\
\text { institutional filter. }\end{array}$ & Selectorate theory. & $\begin{array}{l}\text { Under the current rules of } \\
\text { politics, political leaders' main } \\
\text { motivation is to increase the } \\
\text { chances of their own political } \\
\text { survival, drawing upon their } \\
\text { systemic understanding. }\end{array}$ \\
\hline Lai et al., 2017 [57] & Australia & $\begin{array}{c}\text { To explore owners and } \\
\text { managers of small } \\
\text { tourism firms in relation } \\
\text { to destinations and } \\
\text { non-tourism-induced } \\
\text { changes. }\end{array}$ & Lifestyle goals. & $\begin{array}{l}\text { Semi-structured } \\
\text { interviews. }\end{array}$ & $\begin{array}{l}\text { Coping in mining towns is } \\
\text { impeded by feelings of } \\
\text { powerlessness, perceived } \\
\text { uncertainties, and distrust in } \\
\text { both government and industry. }\end{array}$ \\
\hline
\end{tabular}


Table 1. Cont.

\begin{tabular}{|c|c|c|c|c|c|}
\hline Author and Year & Country & Objectives & Variables & Methods & Results \\
\hline $\begin{array}{l}\text { Broman et al., } \\
2017 \text { [58] }\end{array}$ & Global & $\begin{array}{l}\text { To explore science and } \\
\text { leadership in order to } \\
\text { mitigate threats and } \\
\text { transform current } \\
\text { societies into } \\
\text { sustainable societies. }\end{array}$ & $\begin{array}{l}\text { Science-based } \\
\text { perspective on } \\
\text { leadership towards } \\
\text { sustainability. }\end{array}$ & Thematic review. & $\begin{array}{c}\text { Science cannot only help } \\
\text { people to solve specific } \\
\text { problems, but it can provide a } \\
\text { solid, strategic } \\
\text { systems-derived overview that } \\
\text { is relevant to all of humanity } \\
\text { and actor towards } \\
\text { sustainability. }\end{array}$ \\
\hline Collins, 2017 [59] & Global & $\begin{array}{l}\text { To explore tertiary } \\
\text { education in order to fit } \\
\text { in the chemical } \\
\text { sustainability. }\end{array}$ & $\begin{array}{l}\text { Green and sustainability } \\
\text { bookcase, technology } \\
\text { sustainability campus, } \\
\text { code of sustainability } \\
\text { ethics for leaders. }\end{array}$ & Thematic review. & $\begin{array}{l}\text { Cultural blockades against the } \\
\text { rational advancement of } \\
\text { sustainability within chemical } \\
\text { and sustainability } \\
\text { transformation should address } \\
\text { technical content appropriately } \\
\text { to educate leaders for a } \\
\text { sustainable world. }\end{array}$ \\
\hline $\begin{array}{l}\text { Harpur and Walker, } \\
2017[60]\end{array}$ & USA & $\begin{array}{l}\text { To explore novel safety } \\
\text { biomarkers in different } \\
\text { phases of drug } \\
\text { development by } \\
\text { regulators from } \\
\text { preclinical safety } \\
\text { assessment to clinical } \\
\text { trials. }\end{array}$ & $\begin{array}{l}\text { Safety biomarkers, } \\
\text { regulatory } \\
\text { qualifications. }\end{array}$ & Thematic review. & $\begin{array}{c}\text { Networking and collaboration } \\
\text { among stakeholders, including } \\
\text { less formal or time-intensive } \\
\text { interactions by regulators, e.g., } \\
\text { FDA contributes to significant } \\
\text { decision-making and sustained } \\
\text { leadership. }\end{array}$ \\
\hline Shi, 2016 [61] & $\begin{array}{l}\text { South East Asian } \\
\text { Countries }\end{array}$ & $\begin{array}{c}\text { To assesses competing } \\
\text { outlooks for energy mix } \\
\text { to move toward a green } \\
\text { energy mix. }\end{array}$ & Green energy strategies. & $\begin{array}{l}\text { Thematic review and } \\
\text { SWOT analysis. }\end{array}$ & $\begin{array}{l}\text { Green energy strategies will } \\
\text { require sustained leadership, } \\
\text { political determination, and } \\
\text { concrete actions from } \\
\text { stakeholders, in particular, } \\
\text { national governments across } \\
\text { the region. }\end{array}$ \\
\hline
\end{tabular}

Frangipani Langkawi hotel has adopted transformational leadership roles to contribute to sustainable development in Malaysia via green hotel practices. Therefore, the leadership roles for green hotel practices by the Frangipani include the technical skills for environmental conservation, conceptual skills for green growth, and human skills for social inclusions. Hence, the transformational leadership roles emphasize the three pillars of sustainability, i.e., environmental, economic, and social issues. Technical skills, especially for environmental conservation, are very important for transformational leadership activities. For instance, the Frangipani Langkawi Resort and Spa has effectively separated food waste into three categories, such as bread, rice, and vegetables, following the zero-waste concept for environmental conservation [62]. Most of the food waste was used as animal feed (for ducks, chickens, geese, turkeys, and fish in the constructed wetland pond), and the remaining food waste was composted. However, sustained leadership should have the capacity to deal with decolonial, interdisciplinary, intersectional, and community-engaged approaches and an in-depth encounter with everyday practices of resistance for environmental conservation [6]. Therefore, Frangipani has gone for several levels of trials and errors to perform the appropriate organic waste composting and use of it for environmental conservation in collaboration with researchers and universities. Milner-Gulland et al. [39] also stated that restoring nature while meeting human needs requires a bold vision. The mitigation and conservation hierarchy supports the choice of actions to conserve and restore nature and evaluation of the effectiveness of those actions across sectors and scales. Hence, leadership should know about 'Strategic Environmental Assessment' (SEA) to incorporate community via training for sustainable development [40]. Moreover, the EIA (Environmental Impact Assessment) should maximize its contribution to responsible tourism [47]. Thus, science cannot only help people to solve specific problems, but it can provide a solid, strategic systems-derived overview that is relevant to all of humanity and act towards sustainability [58]. In this regard, Frangipani's collaboration with universities for scientific supports, monitoring, and validation of green hotel activities is in line with the technical skills of transformational leadership roles towards sustainability. 
Similarly, conceptual skills, especially for green growth, are vital for the balance between development and environmental conservation. Frangipani hotel in Langkawi Geopark is one of the hotels in Malaysia that advanced the 'constructed wetland' ecotechnology into their facility since 2009 to reduce the investment of hotel's financial capital in cutting the cost of sewage maintenance and water usage. Moreover, the system itself would indirectly help to ensure more sustainable wastewater and water resource management when the treated wastewater is reused [19,63-65]. Additionally, Frangipani has adopted the rainwater harvesting technology in its facility to reuse the rainwater as well as to reduce the supply water consumption and its associated cost. Contrary, Potdar et al. [42] reported that employers' corporate social responsibility (CSR) involvement influences employee proclivity towards guardianship behavior in shoplifting prevention. A reduction in retail crime contributes towards positive relationships among key stakeholders such as supermarkets, their employees, and society at large based on the social, environmental, and employee welfare practices of supermarkets. The applications of key management tools (such as tools for CSR management, environment management, LCA (life-cycle assessments), and sustainability evaluation indicators) are helpful for managers to integrate sustainability into SMEs' business strategy [43]. Institutional ownership also paves the way to develop new socially responsible investment strategies and ESG (environmental, social, and corporate governance)-oriented practices that help consolidate tourism-related firms' financial performance and positively benefit society (4). Similarly, standards-setting involvements foster innovation mainly through improving firms' R\&D (i.e., research and development) efficiency, reducing financial constraints, and inducing collaborative innovation [45]. Frangipanis' outsourcing to minimize employee expenses is a good example of surviving the tourism business during uncertainties such as the COVID-19 pandemic.

Furthermore, human skills regarding social inclusion in green tourism activities are one of the main preconditions of transformational leadership roles to achieve sustainability. The Frangipani hotel, for example, has developed a community outreach program that aims to educate the public (guests, students, other hotel operators) on the concept of hotel greening. Frangipani provides a 1.5-2 h' eco-walk every day that shows all the practices of green design for energy conservation to the wetland and organic farm [66]. Kim and Hall [38] have also highly addressed the human skills regarding the social inclusion of all consumers for sustainability initiatives. Consumers' attitudes, personal norms, and social norms have positive impacts on their participation in crowdfunding. Education for sustainable development across educational programs brings the solution for complex community problems by engaging businesses and consumers related to sustainability issues [1] Corporate sustainability asserts that the sustainability organizational culture comprising sustainability vision and values leads to emotional commitment among organizational members to attain the vision [41]. Spanish smart cities have considerable scope to improve their use of social media to enhance their communications and branding while prioritizing emotional messages and business events [49]. However, 'uncertain career growth', 'industry dynamism', and 'lack of training programs' are significant barriers to corporate sustainability [48]. Transformative learning that fosters a shift in consciousness towards a more ecological approach is an inherently place-based phenomenon [50]. Analyzing the integrity of the ecovillage is an interdisciplinary subject, which requires a variety of expertise to address the aspects such as energy, building design, water, agriculture, and so on. Therefore, evaluating all dimensions and characteristics of ecovillages is beyond the experience of a researcher [51]. Therefore, networking and collaboration among stakeholders, including less formal or time-intensive interactions by regulators, contribute to significant decision-making and sustained leadership [60]. Hence, the modified theory of transformational and behavioral leadership has been adopted to produce the conceptual framework of sustainability via green hotel practices (Figure 2). 


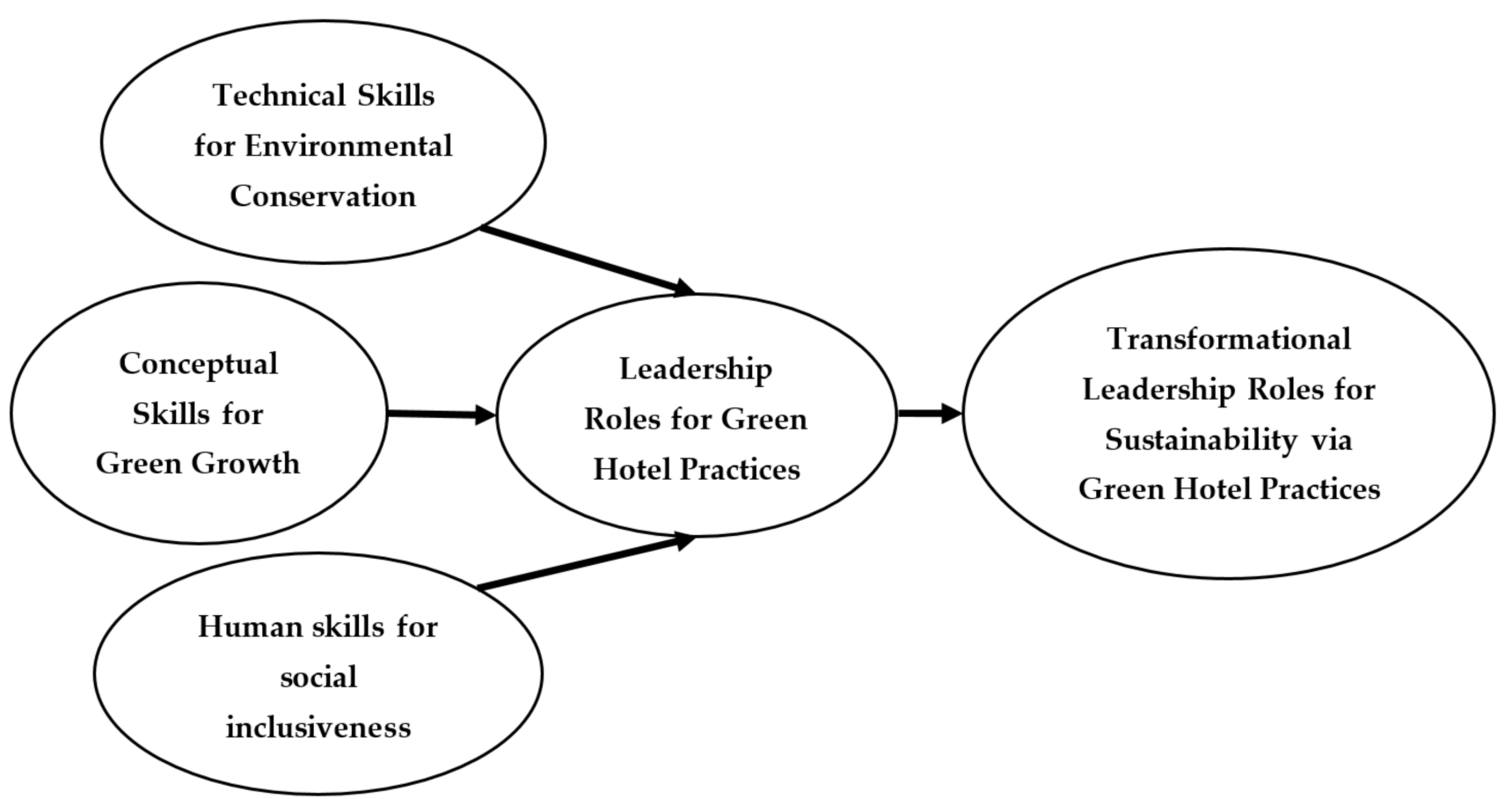

Figure 2. Conceptual framework of sustainability via green hotel practices following modified transformational and behavioral leadership theories.

\section{Methods}

Extensive literature review was conducted to find out the barriers and promotion in green hotel approaches. To find the literature, two popular databases, i.e., Web of Science (WoS) and ScienceDirect, have been chosen for the quality articles, and the keywords search were used 'sustainability leadership' and 'tourism or hospitality'. Total 28 articles written in English were found (i.e., 24 from ScienceDirect and 4 from WoS) from 2015 to 2021. The publication duration 2015-2021 has been selected purposively because of the adoption of Sustainable Development Goals (SDGs) in 2015. Moreover, these 7 years' publications have been chosen to see the research trend on sustainability leadership as well as to explore the sustainable practices, including in the hospitality industry, after the adoption of SDGs.

Informal interviews were conducted with the head of the 10 departments/branches of Frangipani Langkawi Resort and Spa's operation, along with the managing director from December 2018 to March 2019. The 10 operational branches of Frangipani hotel are Environment, Landscape, Housekeeping, Kitchen, Maintenance, Food and Beverage (FnB), Security, Accounting, Front Desk, and Human Resources. The head of these 10 branches, along with the managing director, was asked about the challenges in each branch to have green practices and their current practices. Their recommendation to adopt green practices were also recorded in the tables and figures. Frangipani Hotel agreed to share their available quantitative data on energy consumption (kWh) from 2006 to 2017, water consumption $\left(\mathrm{m}^{3}\right)$ from 2006 to 2017, savings from food production at the Garden of Frangipani from 2008 to 2017, and savings (RM) from recycled materials at Frangipani Hotel in 2017. These available data presented in graphs are collected from the managing director of Frangipani Hotel.

Informal interviews were also conducted with the local authority, government agencies, local community, and business sectors of Langkawi. The qualitative information was used to support the quantitative data as well as illustrated through diagrams and frameworks for sustainable development via the leadership roles of green hotels. The interviewee was asked about their views and opinions on the environmental, economic, and sociocultural sustainability towards green hotel practices for sustainable development. Interviewees were also asked how they can contribute to the leadership roles of Frangipani 
Langkawi Resort and Spa, how they can provide data and information more easily, and help in the coordination of stakeholders for the green hotel practices. Information from the interviews was helpful to draw the framework on the effective multistakeholder platform and sustainable leadership roles of the hospitality industry, i.e., Frangipani Langkawi Resort and Spa.

\section{Barriers of Green Hotel Approach in Malaysia}

Green hotels have become an important business direction for the hospitality industry because of the rise of environmental awareness and carbon reduction trends [67]. Reliability, empathy, environmental communication, green energy, assurance, and tangibility are the important dimensions to promote a green hotel. However, Chan [68] identified six barriers to implementing green practices via adopting the Environmental Management System (EMS) in operation. The barriers identified are the lack of knowledge and skills, lack of professional advice, uncertainty of outcome, lack of certifiers/verifiers, lack of resources, implementation and maintenance costs. Similarly, Kamalulariffin et al. [69] identified five barriers in terms of regulation and government, customer demand, level of competition, greenest at the organization level, and attitude toward change while implementing the green practices. Yusof and Jamaludin [20] also reported higher implementation and maintenance costs of green products and equipment. For instance, energy-saving chiller is more expensive than the traditional one. There are also inadequate green experts and green knowledge mainly because of the comparative recency of green practices in the lodging industry. There is also inadequate enforcement of rules and regulations. Rivera et al. [70] and Scott [71] reported that government has the capacity, via regulation, to pressurize the organization to become green in operation. Although certain green initiatives may reduce the quality of hospitality services, however, in the long run, they may have less environmental impact. For example, using a soap dispenser instead of individual shampoo bottles can reduce a significant amount of waste [72]. Studies have also shown that guests agree to stay in environmentally friendly hotels but are not willing to pay extra for the green practices [73]. Inadequate support from the guests for willingness to pay for green facilities as well as conflicts between the client and the top management are considered as the drawback of green hospitality services. In many cases, it was found that the success of any business to become green in operation solemnly depends on the client's ambition and aspiration [74]. Training staff about green practices takes a lot of time [20], and replacing the trained staff is time-consuming if the staff resign. Green products, equipment, and supplies are limited in the market because of the new strategy of green business in the market. The last barrier identified is the uncertainty of the outcome of green operation. Many operators also believe that a green operation needs more resources and time [68].

In Malaysia, there are inadequate green experts and resources, such as manpower and green equipment, mainly because of comparatively new phenomena in the Malaysian green hotel industry. However, the benefits of the green hotel are various, such as energy, waste, and water-saving, which lead to financial benefits. There are no problems in having networking with green vendors and suppliers in Malaysia, as well as no problems in managing and giving training to the staff for green practices. Therefore, green purchases will have less environmental impact [75]. The staff are encouraged to be involved in green competition activities, art-making programs, green school programs, and green outings for staff. These activities encourage the staff to become more active and interested in green practices [72]. Frangipani is moving forward with the green practice through the 10 components, such as environment division, landscape division, etc., of the hotel. The implementation of green practices such as organic farming, organic compost, etc., at the Frangipani hotel, along with the inclusion of circular economy, can effectively overcome the barriers of green hotel approaches. 


\section{Green Components of Frangipani Hotel}

The general manager of Frangipani hotel informed that the hotel had adopted many green practices, and the environment department among the 10 departments is the most vital one to promote green practices via promoting sustainability science (Figure 3).

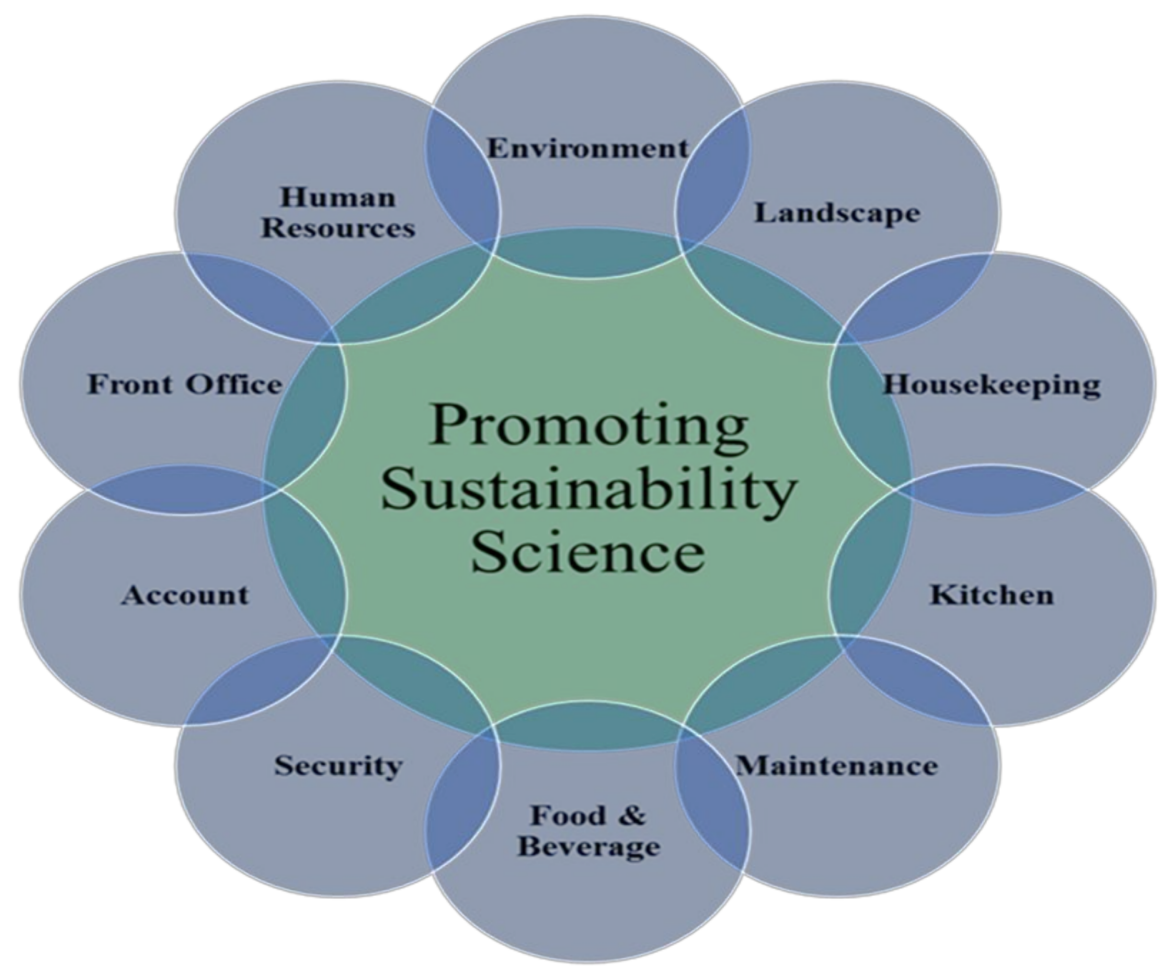

Figure 3. Interrelated components of Frangipani Langkawi Resort and Spa.

Environment: There are five environment officers in the department who train other staff and learners coming from Asia and the Pacific. The behavior and intention of the staff and visitors are very important to continue the green practices. Fortunately, the staff of the hotel are well trained to promote green practices (Table 2). The research officers are also conducting various green experiments such as organic composting and production of black soldier flies for the protein requirement of organic chickens and ducks. Therefore, Frangipani is one of the pioneer green hotels in Malaysia, with more than 200 green practices.

Landscape: The landscape department of the Frangipani hotel is also very important for the natural plantation and beautification of the premises. Several edible and medicinal trees have been planted around the hotel premises to promote traditional values along with health benefits. For instance, the neem tree (i.e., Azadirachta indica) has been planted for its medicinal value as biopesticides.

Housekeeping: Housekeeping department is also practicing the 3Rs (i.e., reduce, reuse, and recycle) concept to promote green practices in Frangipani. For instance, they are using their own produced bio-enzyme to clean the rooms and floors. The department has been creative to reuse old pillow covers by converting them into shopping bags for the visitors coming to the hotel.

Kitchen: The kitchen department of Frangipani follows the zero-waste concept. The department has several green approaches, such as organic composting of food waste, producing washing soap from the used oil in cooking, etc. The department is also using an effective ventilation system on both the upper and bottom end of the room's wall to keep the temperature cool inside the kitchen and reducing energy consumption. The department has also installed shower system tap water supply to reduce water wastage. 
Maintenance: Maintenance department promotes green practices such as using solar energy as well as energy-saving lights. The maintenance department also uses corrugated plastic roofs for the maximum use of sunlight to reduce energy consumption. The hotel also stopped using additional water pumps for the adequate water pressure in the pipeline by introducing vertical flow of water. It is also informed that the supply water pressure by the Taliworks (Langkawi) Sendirian Berhad (Sdn. Bhd.) in Langkawi is adequate now.

Food and Beverage (FnB): Food and beverage department uses organic food produced in the hotel premises. Therefore, there is no issue of chemical poisoning in food, and the practice reduces the expenses of Frangipani while promoting a green image to the guests and visitors. The department informed that about $40 \%$ of the organic food (i.e., mainly vegetable and fruits) requirement of the hotel had been supplied from their own garden on the hotel premise. The remaining $60 \%$ of food comes from the mainland of Peninsular Malaysia. Therefore, the food price that is coming from the mainland is about $30 \%$ higher than the local food price due to the logistic cost. However, there is a good prospect of organic farming at Tuba island of Langkawi with low production cost since there are fewer people with huge cultivable land.

Security: The security staff are trained on green practices and they are also applying green practices. For instance, they are trained on emergency responses such as floods, tsunamis, earthquakes, fire incidents, etc., along with training on first aid. The Frangipani hotel is trying to adopt the UNESCO guideline of emergency responses. They are keeping the check-in records of the guests for security purposes while also checking the firehose regularly.

Accounting: The accounting department also promotes green practices such as using the computer in power-saving mode, printing only if required and printing double-sided. They are also calculating the green incentive remuneration of the staff and displaying it. Therefore, the communication between the hotel owner and the staff has been very effective and strong.

Front Desk: The front desk staff are performing more than 30 green practices, including organic drink serving to the guests. The decoration of the front desk is also from green products. The most important thing is that these front desk staff are also joining other departments in rotation to learn and apply green practices.

Human Resources: Department of Human Resources (HR) encouraged all the staff to promote new green practices in order to reduce energy and water consumption as well as reduce organic waste. The staff receive incentives and other benefits from the hotel owner based on their performance of green practices. HR is also arranging adequate training on green initiatives and practices for the staff and relevant stakeholders.

Table 2. Operational challenges and current green practices at Frangipani Resort.

\begin{tabular}{|c|c|c|}
\hline Sectors & Challenges & Current Practices \\
\hline Environment & No book written on sustainable green hotel practices. & $\begin{array}{l}\text { Frangipani management has recorded more than } 200 \text { green } \\
\text { hotel activities from around the world to be practiced locally. }\end{array}$ \\
\hline Landscape & $\begin{array}{l}\text { Initially, staff cannot link the environment as an } \\
\text { important part of social and economic advancement. }\end{array}$ & $\begin{array}{l}\text { Training programs are ongoing to address environmental, } \\
\text { social, and economic balance. }\end{array}$ \\
\hline Housekeeping & $\begin{array}{l}\text { Most guests are not aware of green housekeeping } \\
\text { practices, which leads to unnecessary washing of } \\
\text { towel, bed cover, etc., every day. }\end{array}$ & Using own produced bio-enzyme to clean rooms and floors. \\
\hline Kitchen & Inorganic and hazardous solid waste management. & Collected by waste collector appointed by local authority. \\
\hline Maintenance & Reducing the use of energy and water. & $\begin{array}{l}\text { Use of corrugated plastic roof for maximum use of sunlight } \\
\text { and introducing vertical flow of water to avoid pressure of } \\
\text { water pump. }\end{array}$ \\
\hline Food and Beverage & $\begin{array}{l}\text { About } 60 \% \text { organic food comes from the mainland of } \\
\text { Peninsular Malaysia, which is more expensive than } \\
\text { the local price. }\end{array}$ & $\begin{array}{l}\text { Increasing the production of organic garden food via } \\
\text { increasing the area of the garden at Frangipani resort. }\end{array}$ \\
\hline Security & $\begin{array}{l}\text { Sea beach erosion along the metal fence around the } \\
\text { boundary is expensive. }\end{array}$ & $\begin{array}{l}\text { Planting coconut trees and the morning glory herb along the } \\
\text { sea beach to reduce erosion. }\end{array}$ \\
\hline
\end{tabular}


Table 2. Cont.

\begin{tabular}{lll}
\hline \multicolumn{1}{c}{ Sectors } & \multicolumn{1}{c}{ Challenges } & \multicolumn{1}{c}{ Current Practices } \\
\hline Accounting & $\begin{array}{l}\text { Traditional hospitality practices are losing a big } \\
\text { number of tourists from Europe and America who } \\
\text { prefer sustainable tourism. }\end{array}$ & $\begin{array}{l}\text { Green practices such as zero-waste concept via composting of } \\
\text { organic waste and construction of wetland for greywater } \\
\text { treatment have been profitable. }\end{array}$ \\
\hline Front Office & $\begin{array}{l}\text { Access cards were used one time, although now } \\
\text { many hotels are using disposable cards. }\end{array}$ & $\begin{array}{l}\text { Less use of paper and envelopes via digitalization of receipts } \\
\text { in email. }\end{array}$ \\
\hline Human Resources & $\begin{array}{l}\text { Staff, including the general managers, are from a } \\
\text { mono discipline. }\end{array}$ & $\begin{array}{l}\text { Training them to multi-task via involving more than the } \\
\text { usual operational activity of Frangipani. }\end{array}$ \\
\hline
\end{tabular}

\section{Green Hotel Practice Based on Science and Technology}

There are several green practices based on science and technology at the Frangipani hotel (Table 3). For instance, currently, there are 34 solar panels have been used in the resort that were set at $45^{\circ} \mathrm{C}$. These solar panels are close-coupled and have a life expectancy of more than 20 years. Meanwhile, panel manufacturers have greatly improved the reliability and efficiency of modern panels compared to their predecessors. Therefore, utilization of this solar technology is becoming economically viable.

Table 3. Some green practices by Frangipani Langkawi Resort and Spa in Malaysia.

\begin{tabular}{|c|c|c|}
\hline Branches & Green Practices & Purposes \\
\hline \multirow{3}{*}{ Passive Architecture } & Corrugated plastic roof & Maximum natural lighting to enter the room. \\
\hline & Green roof and walls & $\begin{array}{l}\text { Reduces room temperature to reduce energy consumption of } \\
\text { air condition. }\end{array}$ \\
\hline & Grease trap & $\begin{array}{l}\text { Intercept grease and solids from kitchen before entering } \\
\text { wastewater system. }\end{array}$ \\
\hline \multirow{4}{*}{ Energy and Lighting } & Solar energy & $\begin{array}{l}\text { Lighting and solar water heaters to provide hot water } \\
\text { in bathrooms. }\end{array}$ \\
\hline & Natural lighting and ventilation & $\begin{array}{l}\text { Larger windows and open space for more light and air to } \\
\text { reduce energy use. }\end{array}$ \\
\hline & Efficient unit of air condition & Reduce energy consumption. \\
\hline & Electric vehicle & Reduce carbon emission. \\
\hline \multirow{3}{*}{ Water Conservation } & Rainwater harvesting & Landscape and vegetable cultivation, toilet flushing. \\
\hline & Water harvesting from air condition & Gardening and irrigation purposes. \\
\hline & Dual flush, low-flow showerhead & Save water consumption. \\
\hline \multirow{2}{*}{ Organic Farming } & $\begin{array}{l}\text { Raised bed, hugelkultur, container garden, } \\
\text { recycling in nursery }\end{array}$ & $\begin{array}{l}\text { Increasing food production, including vertical vegetation and } \\
\text { SRI (system of rice intensification) methods. }\end{array}$ \\
\hline & Black soldier fly larva & $\begin{array}{l}\text { Sustainable protein for aquaculture and animal feed. } \\
\text { Compost organic waste. }\end{array}$ \\
\hline \multirow{3}{*}{ Waste Management } & Leaf composting & Fertilizer and retain water longer in soil. \\
\hline & Organic composting & Organic fertilizer for the garden. \\
\hline & Eco-enzyme and bio-pesticides & Soil fertilizer, detergent to wash floors, and natural pesticide. \\
\hline \multirow{3}{*}{$\begin{array}{l}\text { Biodiversity (Flora } \\
\text { and Fauna) }\end{array}$} & Edible, green, flowering, herb plants & $\begin{array}{l}\text { Organic vegetables, fruits, and drinks. Use in health care and } \\
\text { garden decoration. }\end{array}$ \\
\hline & Organic chicken and duck. & Health protein consumption. \\
\hline & Aquaculture in wetland and pond & $\begin{array}{l}\text { Aquaculture in the naturally treated water to produce } \\
\text { healthy food. }\end{array}$ \\
\hline \multirow{2}{*}{$\begin{array}{l}\text { Wastewater Management } \\
\text { and Innovation }\end{array}$} & Constructed wetland & $\begin{array}{l}\text { Biological wastewater treatment for aquaculture and } \\
\text { irrigation. }\end{array}$ \\
\hline & Solar dehydrate & $\begin{array}{l}\text { Drying is an excellent method of food preservation that } \\
\text { maintains a high level of flavor and nutrients in fruits, } \\
\text { flowers, and excess food. }\end{array}$ \\
\hline $\begin{array}{l}\text { Corporate Social } \\
\text { Responsibility }\end{array}$ & Green education & $\begin{array}{l}\text { Annual night of nature sustainability camp to promote } \\
\text { environmental youth leadership. Environmental knowledge } \\
\text { sharing and eco-walk for the visitors. }\end{array}$ \\
\hline
\end{tabular}




\section{Sustainability Science to Promote Green Hotel}

UNESCO has coined the term 'sustainability science' and defines it as 'Research and education that results in new knowledge, technology, innovation and holistic understanding which will allow societies to better address global and local sustainability challenges' [76]. Sustainability science includes disciplinary, interdisciplinary, and transdisciplinary science. It is also geared towards the generation of basic knowledge, applied technology, sociocultural innovation, as well as towards new governance or social and economic models. Sustainability science is an expression of both academic freedom and responsibility towards societal issues. Therefore, sustainability science to promote green hotel business has received special attention nowadays because of its inclusion of science and technology with the social sciences while implementing green practices at a hotel for sustainable development. The green hotel approach, which is based on the concept of the 3Rs (recycle, reuse, and reduce), has been welcomed due to the depletion of global resources and increasing awareness of environmental protection and ecological conservation [77]. Tourism Council Australia also defines green hotels as natural tourist lodgings developed and managed in environmentally sensitive ways to maintain their business environment and provide guests with green products, green services, and healthy, refreshing, and comfortable accommodations that reflect the features of natural ecologies. While enjoying the naturalistic lodgings, guests could also undergo a living and educational experience and lessons on environmental conservation [77,78]. Similarly, the Green Hotels Association [79] defined green hotels as a means of hotel management that eagerly initiate measures to save water, save energy, and reduce waste in order to protect our planet. Therefore, the green hotel authority should take proactive leadership roles to protect the natural ecosystem through saving water and energy, as well as reducing waste. These approaches to save our planet are only effectively possible via building an environmentally friendly and energy-saving hotel with sustainable management practices.

Green hotels are establishments with environmentally friendly features such as energysaving light bulbs, water-saving toilets, and reusable towels, linen changes on-demand only, waste separation, light sensors, key-cards, etc., with green or environmentally friendly labels [80,81]. Green hotels are environmentally friendly properties whose managers are eager to institute programs that save water, save energy, and reduce solid waste while saving money and protecting the Earth [79]. A characteristic of green hotels is that their services are focused upon preserving the natural ecosystems and delivered with energysaving and carbon-reducing measures. These inclinations are poised to become a major trend in the world's hospitality and food services industry.

The enhanced roles of universities or individual researchers are very important to ensure the quality control and quality assurance of green practices. The green practices obtained from the multistakeholder's platform also need updating and modification by universities or researchers to promote the leadership roles of green hotels for sustainable development (Figure 4). Therefore, the flow of sustainability science is very important for the capacity- and capability-building of the business sector to promote green business. Hence, the university plays vital coordinating roles for the smooth flow of science and technology to the business sector via the multistakeholder's platform. With the support of the multistakeholders' platform, the capacity and capability of the business sector will enhance the effective implementation of green practices because the QA and QC are ensured of the practices via the universities. The university can act as an effective coordinator to gather information about the compliance of these green practices in line with the national and international policies, seek financial support from various sources, and support the business sector with multilevel training and networking to promote green hotel businesses $[82,83]$. 


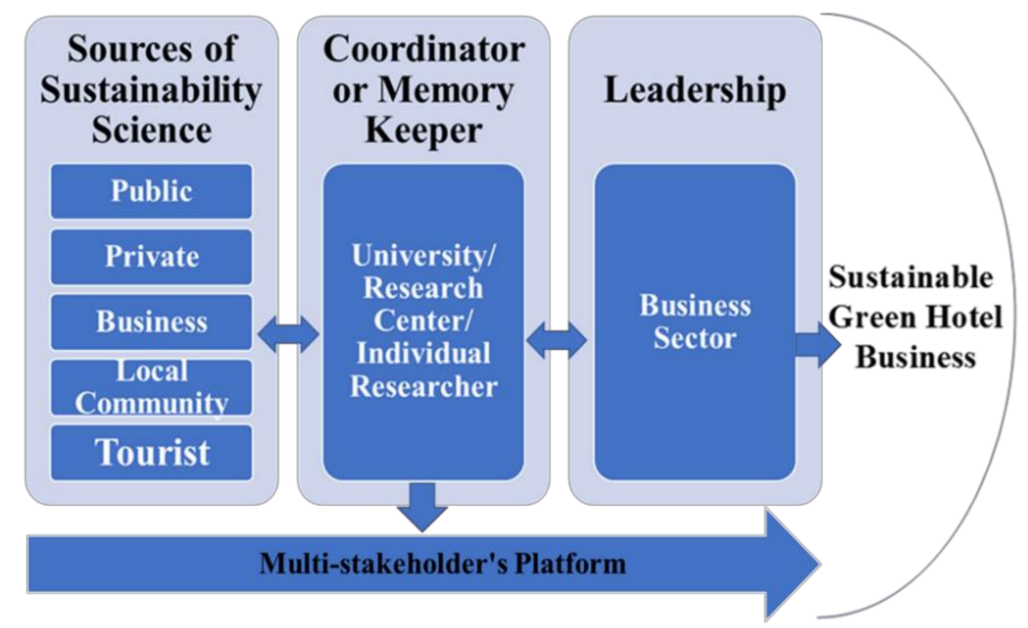

Figure 4. Flow of sustainability science to promote green hotels.

\section{Leadership Roles of Green Frangipani Hotel}

The Frangipani Langkawi Resort and Spa is very proactive in terms of transformational leadership roles to promote green hotels via green practices. The hotel is practicing green and always looking to update the current green practices in addition to including new green practices. The hotel is following a modified circular economy that includes all the green practices. For instance, the Frangipani hotel started waste management from the kitchen following the zero-waste concept. All the food wastes were composted via the organic composting method for reuse as manure and gray and black water were treated in the constructed wetland for the reuse of the water. Okumus et al. [84] also suggested adopting new food composting techniques using advanced yet increasingly accessible innovative chemical and biological approaches to reduce the impact of guest-related food waste in the hospitality industry of the USA. In the Kenyan hospitality industry, the constructed wetlands provide opportunities for wastewater reuse and recovery of resources, as well as improvements in local environmental conditions [85]. Similarly, in Costa Rica, the performance of constructed wetlands in the hospitality industry showed consistent and efficient removal of organic matter and nutrients from the wastewater throughout different seasons and pollutant loads, verifying that such systems can be used in decentralized locations (e.g., tourist areas) in tropical climates [86]. The organic manures from the composting were used in the vegetable and fruit gardens of Frangipani to supply organic food in the kitchen of the hotel, along with the saving of money from the purchase of outsider's food. The System of Rice Intensification (SRI) method has also been applied to yield organic rice with less water and time. The larva of black soldier's fly (BSF) that contain around $60 \%$ protein and $20 \%$ fat is also being reared to supply food to the organic chicken and duck farming. The BSF is also supplied to the third pond of the constructed wetland for fish cultivation. These chicken, duck, and fish make up the organic protein requirement of the hotel. Mertenat et al. [87] reported that cities of lowand middle-income countries face severe challenges in managing the increasing amount of waste produced, especially the organic fraction. Black soldier fly (BSF) biowaste treatment is an attractive treatment option as it offers a solution for waste management while also providing a protein source to help alleviate the rising global demand for animal feed. Black soldier fly (BSF) bioconversion is an emerging technology that can turn food waste into high-protein fish feed through the use of BSF larvae [88]. Therefore, these green practices are a cyclical, economically viable, and sustainable approach because of their inclusion of local community and their wellbeing.

The hotel is also proactive in sharing the information and data of these green practices to the visitors who are coming to the hotel as well as to the wider community of Asia and the Pacific via different events. Frangipani arranges 'eco-walks' voluntarily every Tuesday evening in the hotel to demonstrate the green practices to the guests of the hotel. 
Frangipani also arranges seminars, workshops, and short courses on organic farming for the ASEAN youths as well as to the relevant national and international stakeholders. Frangipani invites speakers from universities, research organizations, government and non-government organizations, and hospitability industries such as the Pacific and the Asia Tourism's Association (PATA) to share their experiences about green hotels. Frangipani hotel authority has also shown its patience in adopting and promoting green practices and educating others about the green hotel business since 2006. The Frangipani hotel, being a member of the Malaysian Hotels Association (MHA), acts as a liaison or coordinator among the government, non-government, business and private sectors, and local communities, along with international agencies, to share the lessons learned about organic farming and composting and the circular economy, in line with the green hotel approaches.

The Frangipani hotel is also promoting scientific experiments based on the green practices at the hotel. For instance, the production of the black soldier flies, which is a future food for humans, will address sustainable development goal 2 (SDG 2), which is zero hunger. Examining the water quality of the constructed wetland to treat the gray and black water for reuse purposes also addresses SDG 6, related to water resources management. Organic composting contributes to reducing carbon emissions and addresses SDG 13 of climate action. Most importantly, the green practices of the Frangipani itself address SDG 8 of decent work and economic growth via sustainable tourism, etc.

The Frangipani hotel authority has very effective and cordial communication with its staff that is essential to promoting green practices. The hotel rewarded the staff in cash for the promotion of green practices, especially in terms of reducing energy and water consumption along with reducing organic waste with innovative ideas. This incentive to the staff is very transparent via the account division of the hotel because the incentives are visible on the board openly. The hotel authority also arranges training on green hotels for the staff both inside and outside of the country to enhance their skill in green practices. However, a multidisciplinary and multistakeholders' platform is required for Frangipani to promote the leadership roles in economic, environmental, social, and cultural sectors via effectively updating the green practices (Figure 5).

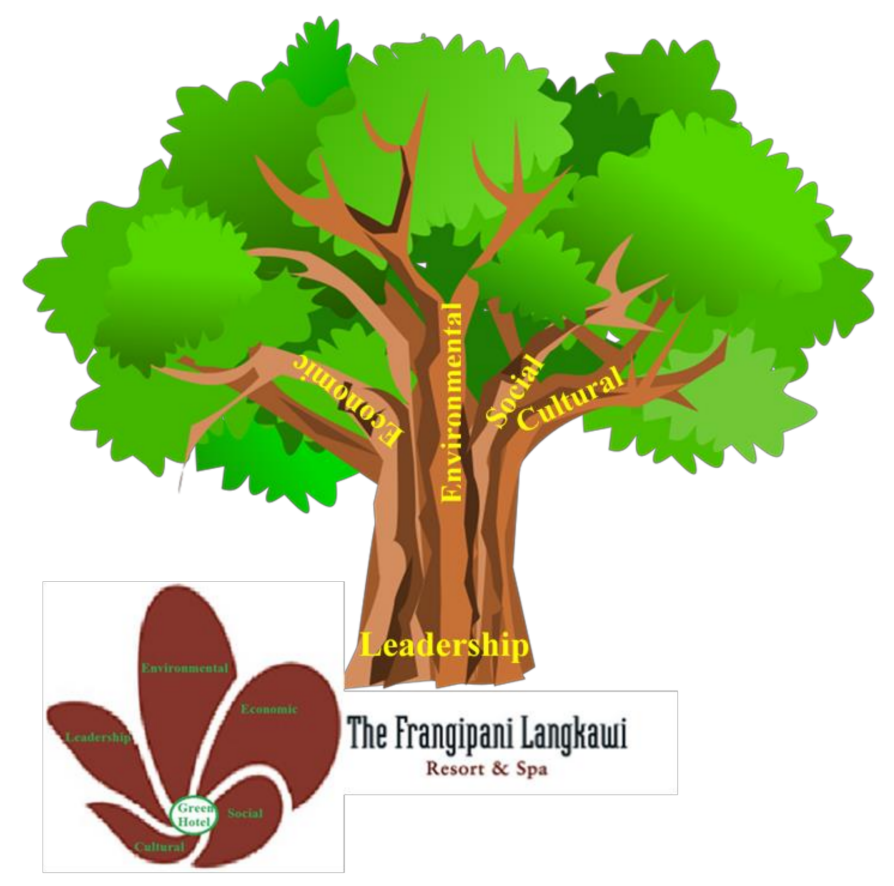

Figure 5. Pillars of Frangipani Resort and Spa to promote a sustainable green hotel. 


\subsection{Environmental Sustainability}

Human civilization has significantly changed the food cycle through the growing use of chemical fertilizers, irrigation needs, energy use, and greenhouse gases emissions. It also reduces the resilience of soil to climate change. Therefore, these anthropogenic activities, including the organic waste incinerated or landfilled, have an important climate impact on local and global environments [89]. Graywater reuse is an attractive green approach for the sustainable management of water in the current water scarcity circumstances [90]. Solid waste and wastewater management have been concerns in the closed system of Langkawi Island for a long time, and they require special attention to reduce the water and soil pollution for the sustainable development of the island [29,91-93]. The constructed wetland at the green hotel to reuse graywater is a low-cost and environmentally friendly technology [83].

Higher energy consumption was recorded in 2007 (70.42 kWh) and 2010 (49.88 kWh) due to the construction of new rooms, swimming pool, and gym, respectively (Figure 6). The average yearly energy consumption per room was steadily decreasing $\left(R^{2}=0.72\right)$ from 2006 to 2017. It was also found that Frangipani had reduced about $46 \%$ of total energy consumption in 2017 compared to 2006.

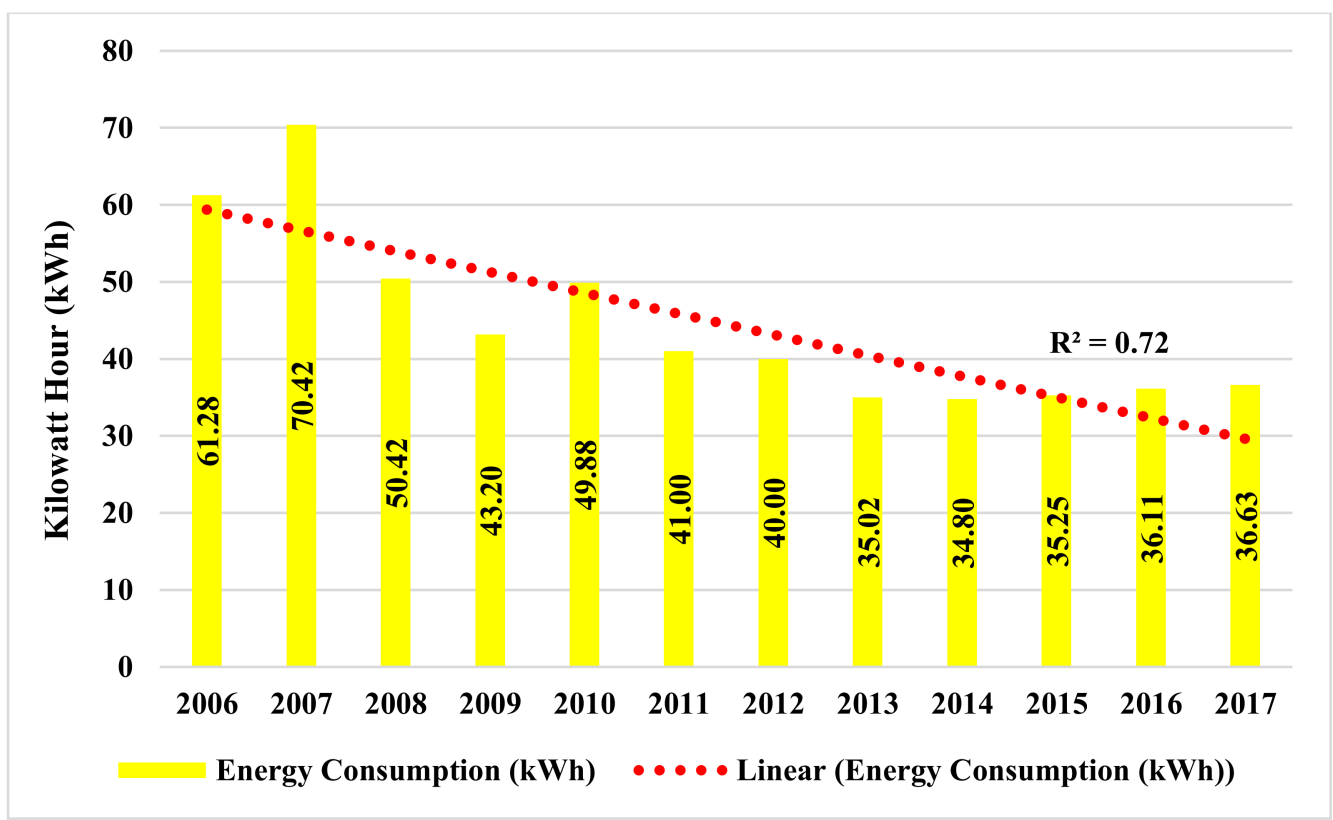

Figure 6. Average per room yearly energy consumption (kWh) from 2006 to 2017 at Frangipani Hotel, Malaysia.

The Frangipani resort has 125 poly tanks, each able to harvest up to $4000 \mathrm{~L}$ of rainwater. Therefore, the total rainwater harvesting capacity is 500,000 L. Water is collected during the rainy days to be used in requirement. The rainwater is collected from the rain gutter, and it goes through the first poly tanks. Then, through a small filtration system connected to a second tank, the water is ready for use. Uses of the rainwater include cleaning of the public pathways, landscapes and vegetable gardens, irrigation purposes, as well as flushing the toilets. The 1.5 and 2 hos power air conditioning unit are also being used in the resort. A total of $20 \mathrm{~L}$ of old paint and $45 \mathrm{~L}$ of chlorine containers have also been reused and placed under each air condition compressor behind the guests' rooms in order to collect condensation from the compressor. The usage of air condition for $12 \mathrm{~h}$ produces about $10 \mathrm{~L}$ of air condition compressor water. This water is then used for irrigating purposes of its surrounding areas. This is a more efficient method of watering plants as it minimizes the need to use paid, treated water. 
Average yearly water consumption per room is decreasing $\left(R^{2}=0.29\right)$ from 2006 to 2017 (Figure 7). Water consumptions were higher in $2009\left(2.36 \mathrm{~m}^{3}\right), 2010\left(2.70 \mathrm{~m}^{3}\right)$, $2012\left(2.27 \mathrm{~m}^{3}\right)$, and $2014\left(1.28 \mathrm{~m}^{3}\right)$ due to the construction of new rooms and landscaping. Moreover, in 2014 a higher number of staff started to stay in staff quarters compared to the previous year. On the other hand, the higher water consumption in $2017\left(2.16 \mathrm{~m}^{3}\right)$ was due to the installation of a new laundry machine. It was informed that the total water consumption at Frangipani reduced by about 34\% in 2017 compared to the water consumption in 2006.

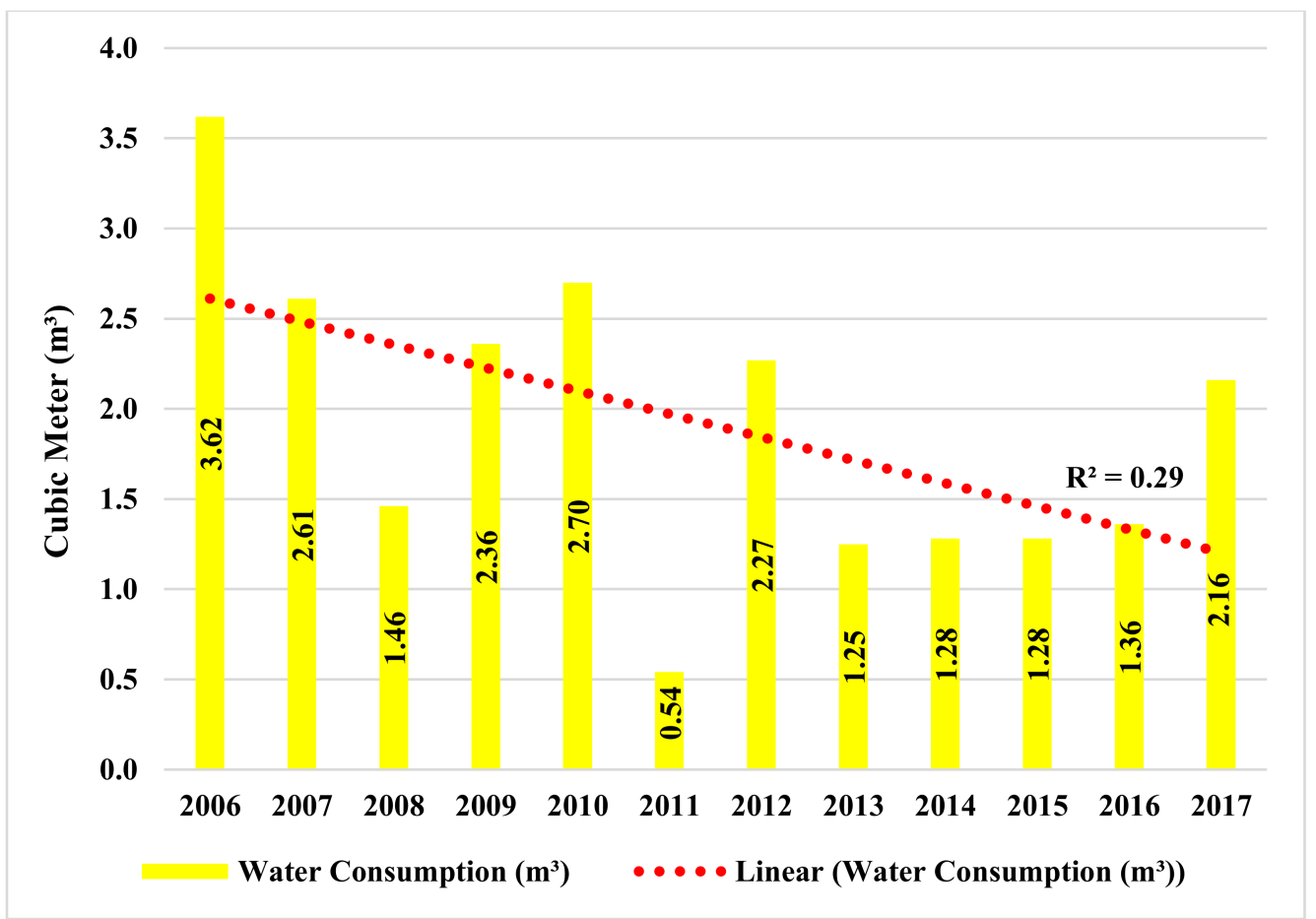

Figure 7. Average per room yearly water consumption $\left(\mathrm{m}^{3}\right)$ from 2006 to 2017 at Frangipani Hotel, Malaysia.

\subsection{Economic Sustainability}

A study on the environmental performance of hotels in Taiwan reported that better environmental performance influences the brand value of the hotel [94]. As climate change can have a great impact on human health, it will require hoteliers to redesign entire Environmental Management Systems with the specific goal of a sustainable quality of life rather than unlimited material growth [94-96]. The human economy can break the circularity of the natural economy following organic farming and organic waste management [89].

Frangipani has an annual saving target of about 10\% in terms of reducing food purchases from outside because guest's perception towards organic farming is more positive than towards genetically modified organisms [97]. Therefore, several vegetables, such as Papaya (Carica papaya), Spinach (Spinacia oleracea), etc., and fruits such as Banana (Musa spp), Jackfruit (Artocarpus heterophylla), etc., are being produced following the organic farming around the Frangipani resort. Thus, on average, about $2061.42 \pm 937.57 \mathrm{~kg}$ of vegetables and fruits were produced per year from 2008 to 2017, and these vegetables and fruits production has saved about an average of 7577.21 $\pm 4003.29 \mathrm{RM}$ per year during the same period (Figure 8). The organic vegetable and fruit production $\left(R^{2}=0.25\right)$, as well as the savings $\left(R^{2}=0.37\right)$ from the food production at the Frangipani, were increasing during 2008 to 2017; however, the reduced production in 2016 was due to erratic rainfall. Frangipani Langkawi Resort and Spa has a very good green practice of recycling materials. In 2017, the hotel saved about 7154.2 $\pm 670.41 \mathrm{RM}$ from different types of recycled materials (Figure 9). Following the zero-waste concept, the hotel saved the following maximum 
amounts of recycled material (RM): recycled metal use, $1985.00 \pm 97.90$ RM; plastic use, $1425.10 \pm 71.26$ RM; recycled oil, $1352.60 \pm 67.63$ RM.
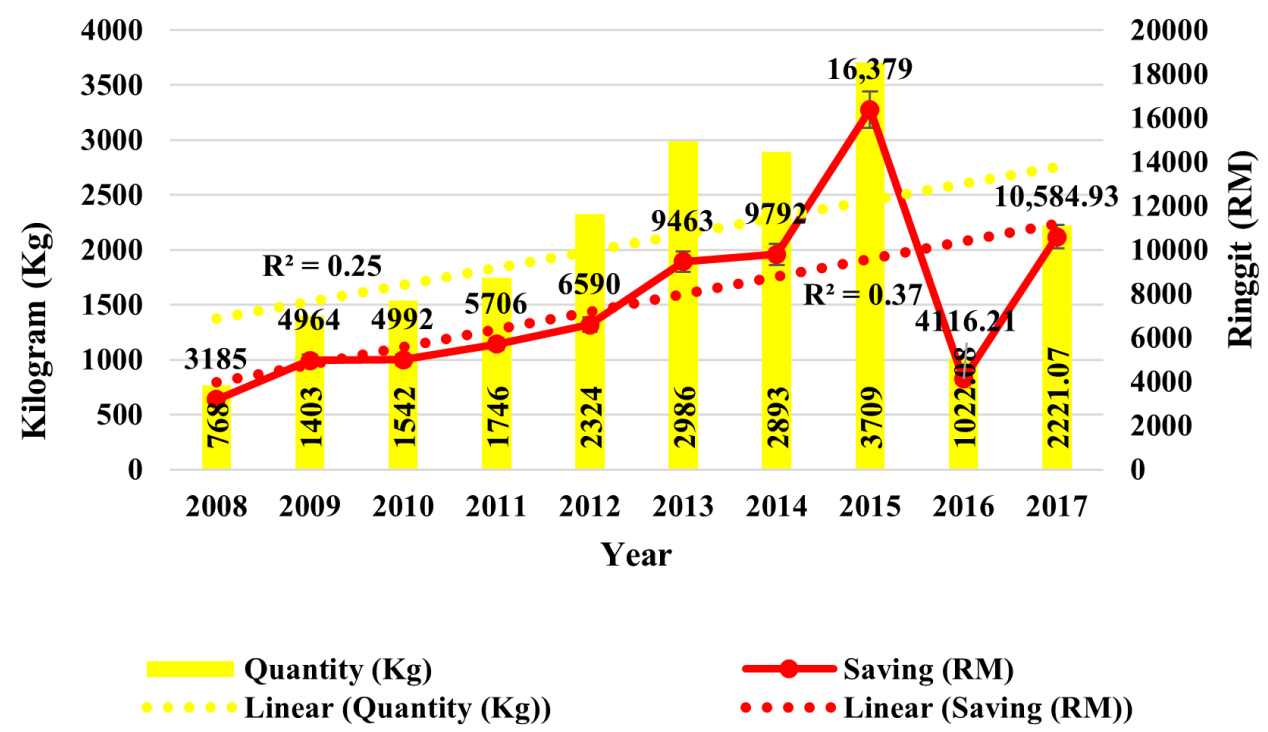

Figure 8. Saving from food production at the garden of Frangipani from 2008 to 2017.

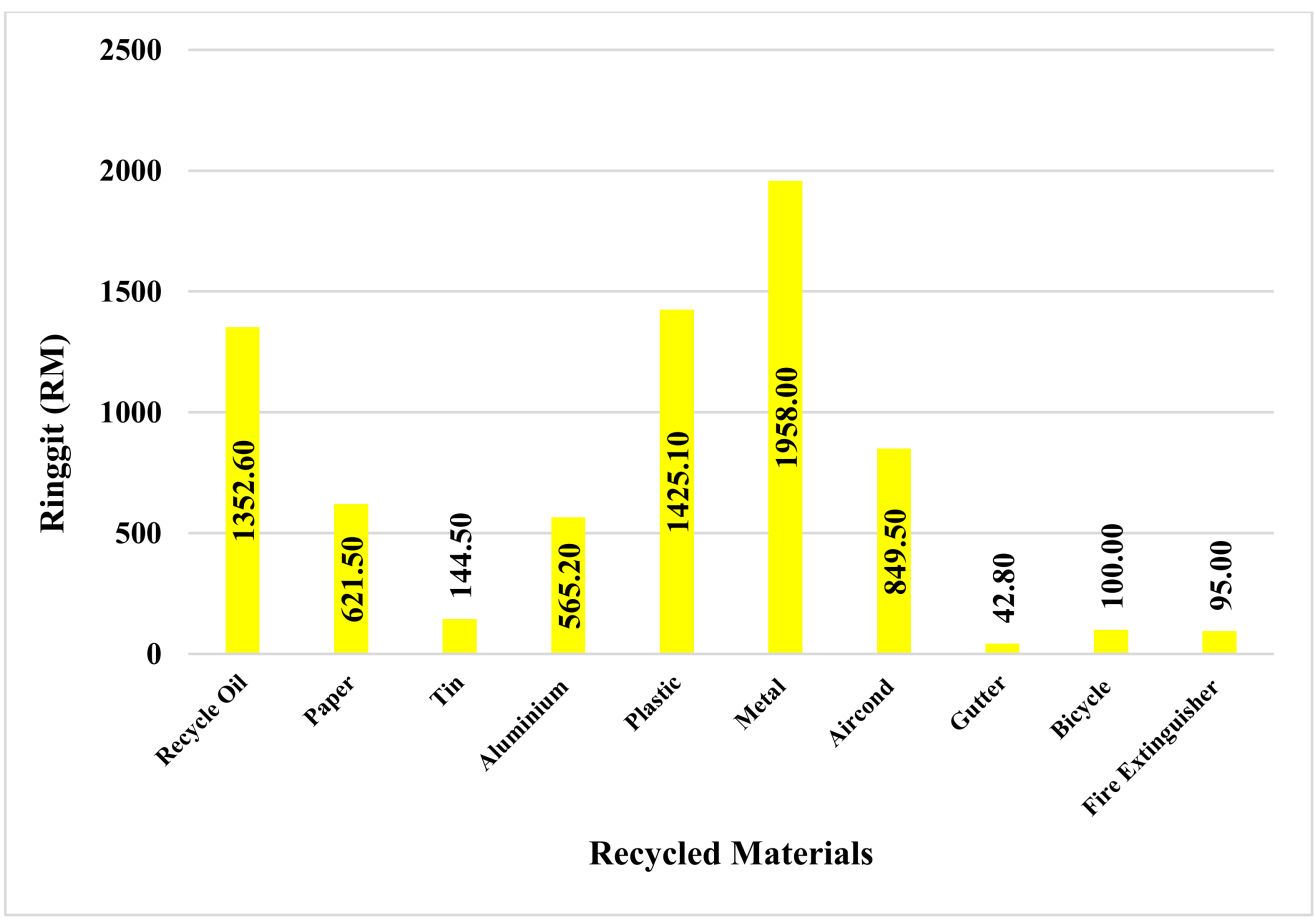

Figure 9. Savings (RM) from recycled materials at Frangipani Hotel, Malaysia, in 2017.

\subsection{Social Sustainability}

A longitudinal study of 87 organizations in the Spanish hospitality industry reported that environmental knowledge has a positive effect on business performance in incorporating the global interest of green initiatives [98]. In the case of Frangipani, the hotel has employed staff from the local community as a means of sustainability and corporate social responsibility. This initiative of hiring local staff can significantly contribute to the socio-economic development of the local community [99]. These staff are also trained and educated on green hotel practices in order to promote sustainable tourism. 


\subsection{Cultural Sustainability}

The Frangipani Langkawi Resort and Spa also ensures cultural sustainability through adopting local healthy food habits while promoting the green hotel business. The hotel also follows the zero-waste concept in line with the local people's aspiration of cleanliness and going green. Local practice and cultural values can promote good environmental management practices within the local communities [100]. Although green practices should be the core of green hotel services via more actions, demonstrations, and evidence, guests should not be overloaded with signages to reiterate that the facility is green. It should be the guest's choice to be going green in line with the hotels' green practices [94]. It also facilitates the hotel authority to introduce new green practices in relation to the customer's choice of green practices. Hence, the hotel authority can play an important role in bringing the local green culture into practice via the appropriate training of the local staff.

\section{Monitoring and Evaluation of Green Hotel}

The hotel industry is responsible for about $21 \%$ of all $\mathrm{CO}_{2}$ emissions related to tourism [18], although several indexes and certifications such as the green building index, Pacific and the Asia Tourism Association's certification, etc., are available for monitoring of the tourism industry. Therefore, effective monitoring and evaluation are required for sustainable tourism that will contribute to sustainable development since the hotel's visitors are more concerned about the environment now [101].

Environmentally friendly goods and services are in higher demand by most tourists nowadays, and they are willing to pay more for eco-friendly services [102]. As hotel management and guests start focusing upon green hotels, effective evaluation of service quality offered by these green hotels would be an important task for the modern hospitality industry. Therefore, to promote the effective green hotel business, the Frangipani Langkawi Resort and Spa at Langkawi needs an innovative and special kind of monitoring and evaluation matrix (Figure 10). This matrix or key performance index should be developed in collaboration with universities to ensure the quality control and quality assurance of the green practices and continuous updating of the practices.

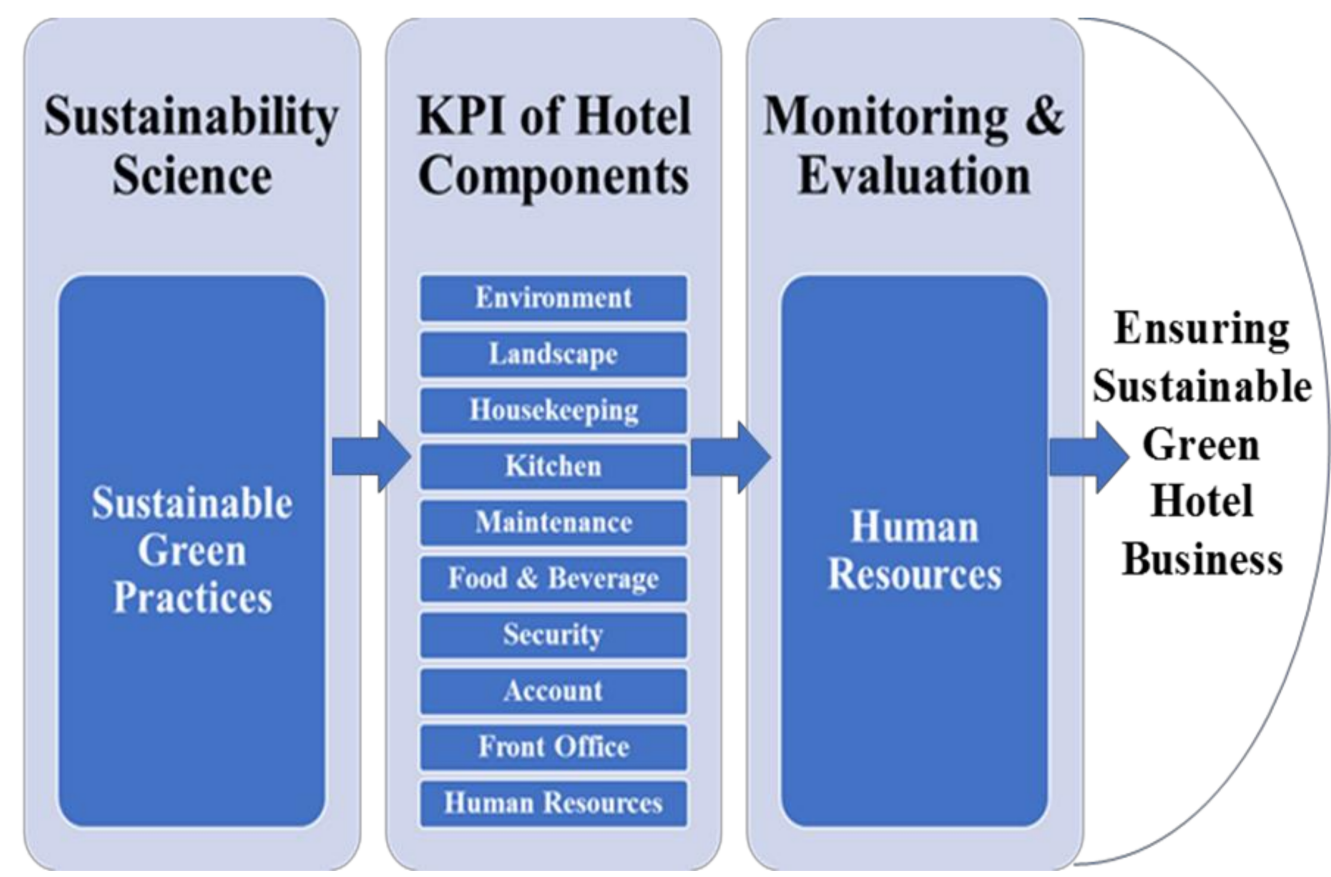

Figure 10. Monitoring and evaluation of green hotel practices. 


\section{Conclusions}

The green hotel has gained much popularity in the hospitability industry because of its contribution towards sustainable development. The Frangipani Langkawi Resort and Spa is one of the champions in Malaysia in promoting green hotel practices. This paper has successfully explored that the Frangipani hotel is carrying out proactive transformational leadership roles through sharing information and data of more than 200 green practices with relevant national and international stakeholders via training, seminars, booklets, demonstrations, etc. Moreover, this paper has highlighted that many green hotel practices of Frangipani can be replicated in different contexts both in and outside of Malaysia. To replicate the green hotel practices in a different context, the effective and functional multistakeholders' platform is very important in order to ensure the flow of sustainability science in the transformational leadership roles of the green hotel as well as the continuous monitoring and evaluations of green practices by the stakeholders. Frangipani has been quite successful in incorporating technical skills such as organic composting for the zero-waste concept in order to contribute to environmental conservation. Similarly, the incorporation of conceptual skills such as wastewater management via constructed wetlands and rainwater harvesting of Frangipani has been fruitful in reducing its operational cost. Furthermore, Frangipani incorporates human skills, such as hiring local employees and arranging several seminars, workshops, and training programs, to build the capacity of multiple stakeholders towards achieving sustainable development via transformational leadership roles of the green hotel. Among many green practices, organic farming and constructed wetland, along with the adoption of a circular economy, have significantly contributed to reduced carbon emissions, safe food supply, and managed water resources. However, these green practices are required to appropriately integrate sustainability education to train multistakeholders to accelerate the achievement of sustainable development goals in Malaysia. Changing the mindset of multistakeholders to being environmentally friendly and choosing green practices while balancing economic and social aspects concerning environmental conservation is the trait of the effective transformational leadership role of Frangipani.

Green hotel approaches in Malaysia are not in the initial stage; rather, there is a good example of green practices by the Frangipani hotel in Langkawi, Malaysia. The green practices at Frangipani are demonstrated to the visitors of the hotels as well as to learners and practitioners from all walks of society. The managing director of the Frangipani hotel is the secretary of the Malaysian Association of Hotels Owner (MAHO) and started training the green practices to the hoteliers of the Asia and the Pacific via the Pacific and Asia Travel Association (PATA). Therefore, the trainee and practitioners have good opportunity to adopt the green practices and implement within their scopes. Frangipani is also conducting experiments of green practices within the hotel premise and networking with universities for the quality control and quality assurance of their green activities. Therefore, the researchers have the opportunity to carry out research and development activities with Frangipani. Moreover, Frangipani is networking with policymakers to include their green practices in the national policy via several seminars, talks, and many other means. Meanwhile, the Frangipani hotel has been awarded several international certifications, such as for green practices. However, the hospitability industry needs significant collaboration with universities and researchers to improve and promote green practices for sustainable development in Malaysia through developing the KPI (Key Performance Index) for effective monitoring and evaluation of green hotels.

Furthermore, to survive the tourism industry, especially considering uncertainties such as the COVID-19 pandemic, local tourism must be promoted with SOP (i.e., standard operating procedure). The ministry must play a significant role because all the publicly listed companies must now employ a full-time sustainability officer, and the same is true for the hospitality and tourism industry. However, there are very few courses and practical approaches for this sustainability officer to be multi-tasking. This requires special training of them via an unusual business training module. Moreover, the current laws should also consider online business activities. Many businesses have already used virtual 
platforms and working from home to save on overhead and full-time employment via casual employment and outsourcing while encouraging existing staff to multi-task in order to be able to pay them more when productivity increase. It is a major crisis to change the mindset of the staff, while the labor laws also need modification to adapt to and adopt the current situation.

Author Contributions: Conceptualization, M.F.A. and M.B.M.; methodology, M.F.A.; software, M.F.A.; validation, M.B.M., C.K.L. and A.W.K.H.; formal analysis, M.F.A.; investigation, M.F.A.; resources, A.W.K.H. and M.F.A.; data curation, M.F.A.; writing-original draft preparation, M.F.A.; writing-review and editing, M.B.M., C.K.L. and K.E.L.; visualization, M.F.A., M.B.M. and C.K.L.; supervision, M.B.M.; project administration, M.F.A.; funding acquisition, M.B.M. All authors have read and agreed to the published version of the manuscript.

Funding: This research was funded by Universiti Kebangsaan Malaysia (UKM), grant number XX-2019-008 and MI-2019-013.

Institutional Review Board Statement: Not applicable.

Informed Consent Statement: Not applicable.

Data Availability Statement: The data presented in this study are available upon reasonable request from the corresponding author.

Acknowledgments: The authors are also grateful for the data and information provided by the Frangipani Langkawi Resort and Spa, Langkawi, Malaysia.

Conflicts of Interest: The authors declare no conflict of interest.

\section{References}

1. Hermann, R.R.; Bossle, M.B. Bringing an entrepreneurial focus to sustainability education: A teaching framework based on content analysis. J. Clean. Prod. 2020, 246, 119038. [CrossRef]

2. Mittal, S.; Dhar, R.L. Effect of green transformational leadership on green creativity: A study of tourist hotels. Tour. Manag. 2016, 57, 118-127. [CrossRef]

3. Abdou, A.H.; Hassan, T.H.; Dief, E.; Moustafa, M. A Description of Green Hotel Practices and Their Role in Achieving Sustainable Development. Sustainability 2020, 12, 9624. [CrossRef]

4. Su, C.H.J.; Chen, C.D. Does sustainability index matter to the hospitality industry? Tour. Manag. 2020, 81, 104158. [CrossRef]

5. Fang, M.; Nguyen, T.H.; Armstrong, A. Developing collective leadership capacity to drive sustainable practices: Destination case of leadership development in Australia. J. Hosp. Tour. Res. 2020. [CrossRef]

6. Apostolopoulou, E.; Chatzimentor, A.; Maestre-Andrés, S.; Requena-i-Mora, M.; Pizarro, A.; Bormpoudakis, D. Reviewing 15 years of research on neoliberal conservation: Towards a decolonial, interdisciplinary, intersectional and community-engaged research agenda. Geoforum 2021, 124, 236-256. [CrossRef]

7. de Jesus Pacheco, D.A.; ten Caten, C.S.; Jung, C.F.; Sassanelli, C.; Terzi, S. Overcoming barriers towards Sustainable ProductService Systems in Small and Medium-sized enterprises: State of the art and a novel Decision Matrix. J. Clean. Prod. 2019, 222, 903-921. [CrossRef]

8. Chung, K.C. Green marketing orientation: Achieving sustainable development in green hotel management. J. Hosp. Mark. Manag. 2020, 29, 722-738. [CrossRef]

9. Nezakati, H.; Hosseinpour, M. Green Tourism Practices in Malaysia; Hassan, H., Nezakati, H., Eds.; Selected Issues in Hospitality and Tourism Sustainability; Universiti Putra Malaysia Press: Serdang, Malaysia, 2014; ISBN 978-967-344-430-4.

10. Rainforest Alliance. FAQ: What Is the Difference Between Green, Eco-, and Sustainable Tourism? 2016. Available online: https: / / www.rainforest-alliance.org/faqs/difference-between-eco-tourism-green-sustainable-travel (accessed on 4 March 2019).

11. Lim, C.K.; Tan, K.L.; Hambira, N. An Investigation on Level of Public Awareness of Green Homes in Malaysia through Web-Based Illustrations. AIP Conf. Proc. 2018, 2016, 020074.

12. Lim, C.K.; Tan, K.L.; Hambira, N. A Proposed Guideline with Building Information Modelling (BIM) for Virtual Transformation of Traditional Housing to Green Housing. Int. J. Sup. Chain. Mgt. 2018, 7, 485-491.

13. IES. What Is Ecotourism?. The International Ecotourism Society. 2019. Available online: https://ecotourism.org/what-isecotourism/ (accessed on 1 July 2021).

14. Brown, M. Environmental policy in the hotel sector: "green" strategy or stratagem? Int. J. Contemp. Hosp. Manag. 1996, 8, 18-23. [CrossRef]

15. Lee, H.; Jai, T.M.; Li, X. Guests' perceptions of green hotel practices and management responses on TripAdvisor. J. Hosp. Tour. Technol. 2016, 7, 182-199. [CrossRef] 
16. Han, H.; Hsu, L.T.J.; Lee, J.S. Empirical investigation of the roles of attitudes toward green behaviors, overall image, gender, and age in hotel customers' eco-friendly decision-making process. Int. J. Hosp. Manag. 2009, 28, 519-528. [CrossRef]

17. Lu, L.C.; Chang, H.H.; Chang, A. Consumer personality and green buying intention: The mediate role of consumer ethical beliefs. J. Bus. Ethics 2015, 127, 205-219. [CrossRef]

18. UNEP \& UNWTO. Tourism in the Green Economy-Background Report; United Nations Environment Programme (UNEP) and World Tourism Organization (UNWTO): Madrid, Spain, 2012. Available online: https://www.e-unwto.org/doi/pdf/10.18111/9789284 414529 (accessed on 12 March 2019).

19. Jones, C. Scenarios for greenhouse gas emissions reduction from tourism: An extended tourism satellite account approach in a regional setting. J. Sustain. Tour. 2013, 21, 458-472. [CrossRef]

20. UNWTO. Transforming Tourism for Climate Action; World Tourism Organization: Madrid, Spain, 2021. Available online: https: //www.unwto.org/sustainable-development/climate-change (accessed on 10 April 2021).

21. UNESCO. Langkawi UNESCO Global Geopark (Malaysia); United Nations Educational, Scientific and Cultural OrganizationL: Paris, France, 2017; Available online: http:/ / www.unesco.org/new/en/natural-sciences/environment/earth-sciences/unesco-globalgeoparks/list-of-unesco-global-geoparks/malaysia/langkawi/ (accessed on 15 March 2019).

22. Komoo, I. Langkawi UNESCO Global Geopark. In Rising to the Challenge: Malaysia's Contribution to SDGs; Mokhtar, M., Lee, K.E., Sivapalan, S., Eds.; Penerbit Universiti Kebangsaan Malaysia: Bangi, Malaysia, 2017.

23. GoogleEarth. Map of the Frangipani Langkawi Resort; Google Earth Pro: Mountain View, CA, USA, 2021.

24. Yusof, Z.B.; Jamaludin, M. Green approaches of Malaysian green hotels and resorts. Procedia-Soc. Behav. Sci. 2013, 85, 421-431. [CrossRef]

25. Gupta, A.; Dash, S.; Mishra, A. All that glitters is not green: Creating trustworthy ecofriendly services at green hotels. Tour. Manag. 2019, 70, 155-169. [CrossRef]

26. Alonso-Almeida, M.D.M.; Álvarez-Gil, M.J. Green Entrepreneurship in Tourism. In The Emerald Handbook of Entrepreneurship in Tourism, Travel and Hospitality; Marios, S., Ed.; Emerald Publishing Limited: Bingley, UK, 2018; pp. 369-386.

27. Hoogmartens, R.; Eyckmans, J.; Van Passel, S. A Hotelling model for the circular economy including recycling, substitution and waste accumulation. Resour. Conserv. Recycl. 2018, 128, 98-109. [CrossRef]

28. Korhonen, J.; Honkasalo, A.; Seppälä, J. Circular economy: The concept and its limitations. Ecol. Econ. 2018, 143, 37-46. [CrossRef]

29. Mokhtar, M.; Ahmed, M.F.; Lee, K.E.; Lubna, A.; Goh, C.T.; Rahmah, E.; Wong, A.K.H. Achieving sustainable coastal environment in Langkawi, Malaysia. Borneo J. Mar. Sci. Aquac. 2017, 1. Available online: http://jurcon.ums.edu.my/ojums/index.php/ BJoMSA (accessed on 10 March 2019).

30. Burns, J.M. Leadership; Harper and Row: New York, NY, USA, 1978.

31. Katou, A.A. Transformational leadership and organisational performance: Three serially mediating mechanisms. Empl. Relat. 2015, 37, 329-353. [CrossRef]

32. Arif, S.; Akram, A. Transformational leadership and organizational performance: The mediating role of organizational innovation. SEISENSE J. Manag. 2018, 1, 59-75. [CrossRef]

33. Majeed, N.; Ramayah, T.; Mustamil, N.M.; Nazri, M.; Jamshed, S. Transformational leadership and organizational citizenship behavior: Modeling emotional intelligence as mediator. Manag. Mark. 2017, 12, 571-590. [CrossRef]

34. Khalili, A. Transformational leadership and organizational citizenship behavior: The moderating role of emotional intelligence. Leadersh. Organ. Dev. J. 2017, 38, 1004-1015. [CrossRef]

35. Watson, J.B. Psychology as the behaviorist views it. Psychol. Rev. 1913, 20, 158-177. [CrossRef]

36. Cherry, K. History and Key Concepts of Behavioral Psychology; Verywell: New York, NY, USA, 2021. Available online: https: / / www.verywellmind.com/behavioral-psychology-4157183\#citation-3 (accessed on 24 June 2021).

37. CFI. Leadership Theories. Vancouver, Canada: Corporate Finance Institute. 2021. Available online: https:/ / corporatefinanceinstitute. $\mathrm{com} /$ resources / careers/soft-skills/leadership-theories / (accessed on 24 June 2021).

38. Kim, M.J.; Hall, C.M. Do value-attitude-behavior and personality affect sustainability crowdfunding initiatives? J. Environ. Manag. 2021, 280, 111827. [CrossRef]

39. Milner-Gulland, E.J.; Addison, P.; Arlidge, W.N.; Baker, J.; Booth, H.; Brooks, T.; Bull, J.W.; Burgass, M.J.; Ekstrom, J.; zu Ermgassen, S.O.; et al. Four steps for the Earth: Mainstreaming the post-2020 global biodiversity framework. One Earth 2021, 4, 75-87. [CrossRef]

40. Del Campo, A.G.; Gazzola, P.; Onyango, V. The mutualism of strategic environmental assessment and sustainable development goals. Environ. Impact Assess. Rev. 2020, 82, 106383. [CrossRef]

41. Kantabutra, S.; Ketprapakorn, N. Toward a theory of corporate sustainability: A theoretical integration and exploration. J. Clean. Prod. 2020, 270, 122292. [CrossRef]

42. Potdar, B.; Garry, T.; McNeill, L.; Gnoth, J.; Pandey, R.; Mansi, M.; Guthrie, J. Retail employee guardianship behaviour: A phenomenological investigation. J. Retail. Consum. Serv. 2020, 54, 102017. [CrossRef]

43. Prashar, A.; Vijaya, S.M. A bibliometric and content analysis of sustainable development in small and medium-sized enterprises. J. Clean. Prod. 2020, 245, 118665. [CrossRef]

44. Stojanovic, T.; Gee, K. Governance as a framework to theorise and evaluate marine planning. Mar. Policy 2020, $120,104115$. [CrossRef] 
45. Zach, F.J.; Nicolau, J.L.; Sharma, A. Disruptive innovation, innovation adoption and incumbent market value: The case of Airbnb. Ann. Tour. Res. 2020, 80, 102818. [CrossRef]

46. Zhang, M.; Wang, Y.; Zhao, Q. Does participating in the standards-setting process promote innovation? Evidence from China. China Econ. Rev. 2020, 63, 101532. [CrossRef]

47. Pope, J.; Wessels, J.A.; Douglas, A.; Hughes, M.; Morrison-Saunders, A. The potential contribution of environmental impact assessment (EIA) to responsible tourism: The case of the Kruger National Park. Tour. Manag. Perspect. 2019, 32, 100557. [CrossRef]

48. Gardas, B.B.; Mangla, S.K.; Raut, R.D.; Narkhede, B.; Luthra, S. Green talent management to unlock sustainability in the oil and gas sector. J. Clean. Prod. 2019, 229, 850-862. [CrossRef]

49. Molinillo, S.; Anaya-Sánchez, R.; Morrison, A.M.; Coca-Stefaniak, J.A. Smart city communication via social media: Analysing residents' and visitors' engagement. Cities 2019, 94, 247-255. [CrossRef]

50. Pisters, S.R.; Vihinen, H.; Figueiredo, E. Place based transformative learning: A framework to explore consciousness in sustainability initiatives. Emot. Space Soc. 2019, 32, 100578. [CrossRef]

51. Barani, S.; Alibeygi, A.H.; Papzan, A. A framework to identify and develop potential ecovillages: Meta-analysis from the studies of world's ecovillages. Sustain. Cities Soc. 2018, 43, 275-289. [CrossRef]

52. Pope, J.; Bond, A.; Cameron, C.; Retief, F.; Morrison-Saunders, A. Are current effectiveness criteria fit for purpose? Using a controversial strategic assessment as a test case. Environ. Impact Assess. Rev. 2018, 70, 34-44. [CrossRef]

53. Tasci, A.D. Testing the cross-brand and cross-market validity of a consumer-based brand equity (CBBE) model for destination brands. Tour. Manag. 2018, 65, 143-159. [CrossRef]

54. Balsas, C.J. When markets reset, will we regain? Planning lessons from across the Atlantic Ocean. Land Use Policy 2017, 65, 78-92. [CrossRef]

55. Guerin, T.F. Evaluating expected and comparing with observed risks on a large-scale solar photovoltaic construction project: A case for reducing the regulatory burden. Renew. Sustain. Energy Rev. 2017, 74, 333-348. [CrossRef]

56. Király, G.; Köves, A.; Balázs, B. Contradictions between political leadership and systems thinking. J. Clean. Prod. 2017, 140, 134-143. [CrossRef]

57. Lai, P.H.; Morrison-Saunders, A.; Grimstad, S. Operating small tourism firms in rural destinations: A social representations approach to examining how small tourism firms cope with non-tourism induced changes. Tour. Manag. 2017, 58, 164-174. [CrossRef]

58. Broman, G.; Robèrt, K.H.; Collins, T.J.; Basile, G.; Baumgartner, R.J.; Larsson, T.; Huisingh, D. Science in support of systematic leadership towards sustainability. J. Clean. Prod. 2017, 140, 17-31. [CrossRef]

59. Collins, T.J. Review of the twenty-three year evolution of the first university course in green chemistry: Teaching future leaders how to create sustainable societies. J. Clean. Prod. 2017, 140, 93-110. [CrossRef]

60. Harpur, E.; Walker, E.G. Qualification of safety biomarkers for use in drug development: What has been achieved and what is the path forward? Curr. Opin. Toxicol. 2017, 4, 66-73. [CrossRef]

61. Shi, X. The future of ASEAN energy mix: A SWOT analysis. Renew. Sustain. Energy Rev. 2016, 53, 672-680. [CrossRef]

62. Kasavan, S.; Mohamed, A.F.; Halim, S.A. Drivers of food waste generation: Case study of island-based hotels in Langkawi, Malaysia. Waste Manag. 2019, 91, 72-79. [CrossRef]

63. Elfithri, R.; Mokhtar, M.B.; Abdullah, M.P. Water and environmental sustainability in Langkawi UNESCO Global Geopark, Malaysia: Issues and challenges towards sustainable development. Arab. J. Geosci. 2021, 14, 1168. [CrossRef]

64. Akhir, M.S.A.M.; Amir, A.A.; Mokhtar, M.; Hooi, A.W.K. Constructed Wetland for Wastewater Treatment: A Case Study at Frangipani Resort, Langkawi. Int. J. Malay World Civilis. 2016, 4, 21-28.

65. Akhir, M.S.A.M.; Amir, A.A.; Mokhtar, M.B. Nutrients and Pollutants Removal in Small-Scale Constructed Wetland in Frangipani Resort Langkawi, Malaysia. Nat. Environ. Pollut. Technol. 2017, 16, 569-577.

66. Kasim, A.; Gursoy, D.; Okumus, F.; Wong, A. The importance of water management in hotels: A framework for sustainability through innovation. J. Sustain. Tour. 2014, 22, 1090-1107. [CrossRef]

67. Lee, W.H.; Cheng, C.C. Less is more: A new insight for measuring service quality of green hotels. Int. J. Hosp. Manag. 2018, 68, 32-40. [CrossRef]

68. Chan, E.S. Barriers to EMS in the hotel industry. Int. J. Hosp. Manag. 2008, 27, 187-196. [CrossRef]

69. KamalulAriffin, N.S.; Khalid, S.N.A.; Wahid, N.A. The barriers to the adoption of environmental management practices in the hotel industry: A study of Malaysian hotels. Bus. Strategy Ser. 2013, 14, 106-117. [CrossRef]

70. Rivera, J.; Oetzel, J.; Starik, M. Business responses to environmental and social protection policies: Toward a framework for analysis. Policy Sci. 2009, 42, 3-32. [CrossRef]

71. Scott, W.R. Institutional theory: Contributing to a theoretical research program. In Great Minds in Management: The Process of Theory Development; Smith, K.G., Hitt, M.A., Eds.; Oxford University Press: Oxford, UK, 2005; Volume 37, pp. 460-484.

72. Yusof, Z.B.; Jamaludin, M. Barriers of Malaysian green hotels and resorts. Procedia-Soc. Behav. Sci. 2014, 153, 501-509. [CrossRef]

73. Manaktola, K.; Jauhari, V. Exploring consumer attitude and behaviour towards green practices in the lodging industry in India. Int. J. Contemp. Hosp. Manag. 2007, 19, 364-377. [CrossRef]

74. Aziz, N.A.A.; Foong, S.Y.; Ong, T.S.; Senik, R.; Attan, H.; Arshad, Y. Intensity of market competition, strategic orientation and adoption of green initiatives in Malaysian public listed companies. Int. J. Product. Perform. Manag. 2018, 67, 1334-1351. [CrossRef] 
75. Neto, B.; Caldas, M.G. The use of green criteria in the public procurement of food products and catering services: A review of EU schemes. Environ. Dev. Sustain. 2018, 20, 1905-1933. [CrossRef]

76. UNESCO. Broadening the Application of the Sustainability Science Approach; United Nations Educational, Scientific and Cultural Organization (UNESCO): Paris, France, 2021. Available online: https:/ / en.unesco.org/sustainability-science/guidelines (accessed on 1 July 2021).

77. Han, H.; Kim, Y. An investigation of green hotel customers' decision formation: Developing an extended model of the theory of planned behavior. Int. J. Hosp. Manag. 2010, 29, 659-668. [CrossRef]

78. Berezan, O.; Raab, C.; Yoo, M.; Love, C. Sustainable hotel practices and nationality: The impact on guest satisfaction and guest intention to return. Int. J. Hosp. Manag. 2013, 34, 227-233. [CrossRef]

79. Green Hotels Association (GHA). Why Should Hotels Be Green? 2019. Available online: http://greenhotels.com/index.php (accessed on 12 March 2019).

80. Kaiser, F.G.; Oerke, B.; Bogner, F.X. Behavior-based environmental attitude: Development of an instrument for adolescents. J. Environ. Psychol. 2007, 27, 242-251. [CrossRef]

81. Millar, M.; Baloglu, S. Hotel guests' preferences for green hotel attributes. In Hospitality Management; The University of San Francisco: San Francisco, CA, USA, 2008. Available online: https://repository.usfca.edu/hosp/5 (accessed on 12 March 2019).

82. Ahmed, M.F.; Mokhtar, M.B.; Alam, L.; Mohamed, C.A.R.; Ta, G.C. Non-carcinogenic Health Risk Assessment of Aluminium Ingestion Via Drinking Water in Malaysia. Expo. Health 2019, 11, 167-180. [CrossRef]

83. Ahmed, M.F.; Mokhtar, M.; Alam, L.; Ta, G.C.; Lee, K.E.; Rasyikah, M.K. Recognition of Local Authority for Better Management of Drinking Water at the Langat River Basin, Malaysia. Int. J. Eng. Technol. 2018, 7, 148-154. [CrossRef]

84. Okumus, B.; Taheri, B.; Giritlioglu, I.; Gannon, M.J. Tackling food waste in all-inclusive resort hotels. Int. J. Hosp. Manag. 2020, 88,102543 . [CrossRef]

85. Makopondo, R.O.; Rotich, L.K.; Kamau, C.G. Potential Use and Challenges of Constructed Wetlands for Wastewater Treatment and Conservation in Game Lodges and Resorts in Kenya. Sci. World J. 2020, 2020, 9184192. [CrossRef]

86. Pérez-Salazar, R.; Mora-Aparicio, C.; Alfaro-Chinchilla, C.; Sasa-Marín, J.; Scholz, C.; Rodríguez-Corrales, J.Á. Biogardens as constructed wetlands in tropical climate: A case study in the Central Pacific Coast of Costa Rica. Sci. Total. Environ. 2019, 658, 1023-1028. [CrossRef]

87. Mertenat, A.; Diener, S.; Zurbrügg, C. Black Soldier Fly biowaste treatment-Assessment of global warming potential. Waste Manag. 2019, 84, 173-181. [CrossRef]

88. Cheng, J.Y.; Chiu, S.L.; Lo, I.M. Effects of moisture content of food waste on residue separation, larval growth and larval survival in black soldier fly bioconversion. Waste Manag. 2017, 67, 315-323. [CrossRef]

89. Masullo, A. Organic wastes management in a circular economy approach: Rebuilding the link between urban and rural areas. Ecol. Eng. 2017, 101, 84-90. [CrossRef]

90. Dominguez, S.; Laso, J.; Margallo, M.; Aldaco, R.; Rivero, M.J.; Irabien, Á.; Ortiz, I. LCA of greywater management within a water circular economy restorative thinking framework. Sci. Total. Environ. 2018, 621, 1047-1056. [CrossRef]

91. Mokhtar, M.; Tajam, J.; Wagiman, S. Determination of the Sediment Contamination Level in Dangli Waters of Langkawi UNESCO Global Geopark, Kedah, Malaysia. Sains Malays. 2019, 48, 45-59. [CrossRef]

92. Mokhtar, M.B.; Ta, G.C.; Murad, M.W. An essential step for environmental protection: Towards a sound chemical management system in Malaysia. J. Chem. Health Saf. 2010, 17, 13-20. [CrossRef]

93. Mokhtar, M.; Awaluddin, A.; Tan, M.; Yasin, Z. Trace Metals in Langkawi coral and sediment: A study using AAS and XRF. Malays. J. Anal. Sci. 2001, 7, 189-196.

94. Chen, L.F. Hotel chain affiliation as an environmental performance strategy for luxury hotels. Int. J. Hosp. Manag. 2019, 77, 1-6. [CrossRef]

95. Watts, N.; Adger, W.N.; Agnolucci, P.; Blackstock, J.; Byass, P.; Cai, W.; Cox, P.M. Health and climate change: Policy responses to protect public health. Lancet 2015, 386, 1861-1914. [CrossRef]

96. Costanza, R.; de Groot, R.; Sutton, P.; Van der Ploeg, S.; Anderson, S.J.; Kubiszewski, I.; Turner, R.K. Changes in the global value of ecosystem services. Glob. Environ. Chang. 2014, 26, 152-158. [CrossRef]

97. Wunderlich, S.; Gatto, K.; Smoller, M. Consumer knowledge about food production systems and their purchasing behavior. Environ. Dev. Sustain. 2018, 20, 2871-2881. [CrossRef]

98. Martinez-Martinez, A.; Cegarra-Navarro, J.G.; Garcia-Perez, A.; Wensley, A. Knowledge agents as drivers of environmental sustainability and business performance in the hospitality sector. Tour. Manag. 2019, 70, 381-389. [CrossRef]

99. Aminudin, N. Corporate social responsibility and employee retention of 'Green'Hotels. Procedia-Soc. Behav. Sci. 2013, 105, 763-771. [CrossRef]

100. Aniah, P.; Yelfaanibe, A. Environment, development and sustainability of local practices in the sacred groves and shrines in Bongo District: A bio-cultural study for environmental management in Ghana. Environ. Dev. Sustain. 2017, 20, 2487-2499. [CrossRef]

101. Vassiliadis, C.A.; Fotiadis, A.; Piper, L.A. Analysis of rural tourism websites: The case of Central Macedonia. Tour. Int. Multidiscip. J. Tour. 2013, 8, 247-263.

102. Accenture. Long-Term Growth, Short-term Differentiation and Profits from Sustainable Products and Services: A Global Survey of Business Executives. 2012. Available online: http:/ / www.ddline.fr/wp-content/uploads/2012/12/Accenture-Long-TermGrowth-Short-Term-Differentiation-and-Profits-from-Sustainable-Products-and-Services1.pdf (accessed on 12 March 2019). 